\title{
Pharmacological Modulators of Autophagy as a Potential Strategy for the Treatment of COVID-19
}

\author{
Gustavo José da Silva Pereira ${ }^{1, *(\mathbb{D}}$, Anderson Henrique França Figueredo Leão ${ }^{1}{ }^{\mathbb{D}}$, Adolfo Garcia Erustes ${ }^{1} \mathbb{D}^{\mathbb{D}}$, \\ Ingrid Beatriz de Melo Morais ${ }^{1}$, Talita Aparecida de Moraes Vrechi ${ }^{1}$, Lucas dos Santos Zamarioli ${ }^{1}{ }^{\mathbb{D}}$, \\ Cássia Arruda Souza Pereira ${ }^{1}$, Laís de Oliveira Marchioro ${ }^{1}$, Letícia Paulino Sperandio ${ }^{1}$, Ísis Valeska Freire Lins ${ }^{1}$, \\ Mauro Piacentini ${ }^{2,3}$, Gian Maria Fimia ${ }^{3,4}\left({ }^{\circledR}\right.$, Patrícia Reckziegel ${ }^{1}$, , Soraya Soubhi Smaili ${ }^{1}$ (D) \\ and Claudia Bincoletto ${ }^{1}$ (i)
}

Citation: Pereira, G.J.d.S.; Leão, A.H.F.F.; Erustes, A.G.; Morais, I.B.d.M.; Vrechi, T.A.d.M.; Zamarioli, L.d.S.; Pereira, C.A.S.; Marchioro, L.d.O.; Sperandio, L.P.; Lins, Í.V.F.; et al. Pharmacological Modulators of Autophagy as a Potential Strategy for the Treatment of COVID-19. Int. J. Mol. Sci. 2021, 22, 4067. https://doi. org/10.3390/ijms22084067

Academic Editor: George

J. Kontoghiorghes

Received: 30 December 2020

Accepted: 15 March 2021

Published: 15 April 2021

Publisher's Note: MDPI stays neutral with regard to jurisdictional claims in published maps and institutional affiliations.

Copyright: (c) 2021 by the authors. Licensee MDPI, Basel, Switzerland. This article is an open access article distributed under the terms and conditions of the Creative Commons Attribution (CC BY) license (https:// creativecommons.org/licenses/by/ $4.0 /)$.
1 Department of Pharmacology, Escola Paulista de Medicina, Universidade Federal de São Paulo (UNIFESP), 04044-020 São Paulo, Brazil; anderson.leao@unifesp.br (A.H.F.F.L.); adolfo.erustes@gmail.com (A.G.E.); indiemmorais@gmail.com (I.B.d.M.M.); talitavrechi@gmail.com (T.A.d.M.V.); lucaszamarioli@gmail.com (L.d.S.Z.); cassia.aspereira@gmail.com (C.A.S.P.); 1.marchioro@unifesp.br (L.d.O.M.); leticiasperandio7@gmail.com (L.P.S.); isis.valeska.lins@gmail.com (Í.V.F.L.); reckziegel.patricia@unifesp.br (P.R.); ssmaili@unifesp.br (S.S.S.); claudia.bincoletto@unifesp.br (C.B.)

2 Department of Biology, University of Rome "Tor Vergata", 00133 Rome, Italy; mauro.piacentini@uniroma2.it 3 Department of Epidemiology and Preclinical Research, National Institute for Infectious Diseases IRCCS ‘La Zaro Spallanzani', 00149 Rome, Italy; gianmaria.fimia@inmi.it

4 Department of Molecular Medicine, University of Rome La Sapienza, 00185 Rome, Italy

* Correspondence: gustavo.pereira@unifesp.br; Tel.: +55-11-5576-4449

Abstract: The family of coronaviruses (CoVs) uses the autophagy machinery of host cells to promote their growth and replication; thus, this process stands out as a potential target to combat COVID19. Considering the different roles of autophagy during viral infection, including SARS-CoV-2 infection, in this review, we discuss several clinically used drugs that have effects at different stages of autophagy. Among them, we mention (1) lysosomotropic agents, which can prevent CoVs infection by alkalinizing the acid $\mathrm{pH}$ in the endolysosomal system, such as chloroquine and hydroxychloroquine, azithromycin, artemisinins, two-pore channel modulators and imatinib; (2) protease inhibitors that can inhibit the proteolytic cleavage of the spike CoVs protein, which is necessary for viral entry into host cells, such as camostat mesylate, lopinavir, umifenovir and teicoplanin and (3) modulators of $\mathrm{PI} 3 \mathrm{~K} / \mathrm{AKT} / \mathrm{mTOR}$ signaling pathways, such as rapamycin, heparin, glucocorticoids, angiotensinconverting enzyme inhibitors (IECAs) and cannabidiol. Thus, this review aims to highlight and discuss autophagy-related drugs for COVID-19, from in vitro to in vivo studies. We identified specific compounds that may modulate autophagy and exhibit antiviral properties. We hope that research initiatives and efforts will identify novel or "off-label" drugs that can be used to effectively treat patients infected with SARS-CoV-2, reducing the risk of mortality.

Keywords: COVID-19; autophagy; pharmacology

\section{Introduction}

Coronavirus disease 2019 (COVID-19) is a severe acute respiratory syndrome caused by the infectious coronavirus SARS-CoV-2 [1,2]. It was first described by the Chinese Center for Disease Control and Prevention in December 2019 as a mysterious viral respiratory disease that emerged in the city of Wuhan, Hubei province, China. On 12 January 2020, the World Health Organization (WHO) temporarily named the virus as the 2019 novel coronavirus (2019-nCoV), and by the end of the same month declared it a "public health emergency of international interest" [3]. Later, after phylogenetic analysis, this coronavirus (CoV) was officially named as the severe acute respiratory syndrome coronavirus 2 (SARSCoV-2) [4]. On 11 February 2020, the WHO announced that the disease caused by the 
SARS-CoV-2 would be called "COVID-19", and by the end of March it had already spread across five continents of the world resulting in some sort of lockdown for $1 / 3$ of humanity. Only in 2 September 2020, WHO recommended corticosteroids as an effective treatment for seriously ill COVID-19 patients, but global deaths kept rising reaching 1 million by the end of the same month. Several other drugs were clinically used in the same effort to contain the deaths caused by COVID-19. Finally, only in December 2020, the Medicines and Healthcare products Regulatory Agency (MHRA) in the United Kingdom and the Food and Drug Administration (FDA) in the United States of America (USA) authorized the emergency use of Pfizer/BioNTech's and Moderna's vaccines against COVID-19 [5]. Nevertheless, worldwide vaccine plans are yet to be implemented and novel mutations of the SARS-CoV-2 are rapidly emerging [6,7] demanding continuous research on therapeutics to manage COVID-19. By the end of February 2021, the number of global deaths related to COVID-19 was close to 2.5 million.

\section{Coronavirus: Concepts; Types; Compositions; Mechanisms of Infection and Replication}

The SARS-CoV-2 is a new viral strain of the coronavirus (CoV) family. It belongs to the Betacoronavirus genus ( $\beta-\mathrm{CoVs}$ ) [8] and represents the third $\mathrm{CoV}$ outbreak in the last 20 years, following the severe acute respiratory syndrome coronavirus (SARS-CoV) $[9,10]$ and the Middle-East Respiratory Syndrome coronavirus (MERS-CoV) [11]. Individuals who were previously infected with these $\mathrm{CoVs}$, and those infected with SARS-CoV-2, present similar symptoms, which include dry cough, fever, headache, dyspnea and pneumonia $[1,12,13]$. Most patients that test positive for COVID-19 (about 80\%) are asymptomatic or exhibit mild to moderate symptoms, however, approximately $15 \%$ of them progress to severe pneumonia and about $5 \%$ die due to acute respiratory distress syndrome, septic shock and/or multiple organ failure. The overall mortality rate of SARS-CoV-2 is estimated to be between 3 and $5 \%[1,14]$.

The genome of CoVs consists of a single-stranded RNA, and a notable translation product is the transmembrane spike S-glycoprotein expressed on the surface. Each spike monomer is composed of an S1 subunit and S2 subunit, which are known to bind to membrane receptors present on the surface of human cells. In the case of SARS-CoV2 , it binds to the host cell angiotensin-converting enzyme 2 (ACE2) receptor [15], the same cell surface target as SARS-CoV [2], through the action of the S1 subunit. Previous research showed that the ACE2 protein is associated to the transmembrane serine protease 2 (TMPRSS2), which cleaves S2, generating $\mathrm{S2}^{\prime}$ and promotes the virus-cell membrane fusion [16]. In this sense, ACE2 and TMPRSS2 are crucial for SARS-CoV-2 infection and potential pharmacological targets for COVID-19 treatment.

The ACE2 protein belongs to the membrane-bound carboxypeptidase family and is responsible for converting angiotensin II to angiotensin [1-7]. It is widely distributed throughout the human body, with supramaximal levels in the small intestine, testis, kidneys, heart, thyroid, adipose tissue, colon, liver, bladder, adrenal glands and lungs (mainly in type II alveolar cells) and macrophages. Lower ACE2 levels are found in the blood, spleen, bone marrow, brain, blood vessels and muscles [17]. Thus, understanding how the expression of ACE2 affects SARS-CoV-2 infection is important for the development of preventive/curative measures against infection. Analysis of the SARS-CoV-2-S protein revealed almost $80 \%$ amino-acid identity with the SARS-CoV-S protein [18].

In addition, cathepsin-mediated protein $S$ cleavage is also a critical step for SARS$\mathrm{CoV}-2$ infection, as the acidic $\mathrm{pH}$ in lysosomes influences the entry of the virus into human cells [19]. Currently, it is understood that after the release of the genomic RNA into the cytoplasm, the viral replicase nonstructural proteins 3 and 4 (nsp3 and nsp4) are translated, which initiates the rearrangement of the endoplasmic reticulum (ER) membranes into double-membrane vesicles (DMVs) [20,21]. It has been speculated that the DMVs accommodate viral RNA replication $[20,22,23]$. Next, in the ER and Golgi intermediate compartment, the newly synthesized genomic RNA molecules are assembled into virions [24], and the infectious virions are transported to the secretory pathway where they are 
released by exocytosis [25]. Herein, we will discuss all the steps involved in the replication of SARS-CoVs using the autophagy machinery.

\section{Coronavirus Hijack the Autophagy Machinery to Foster Replication}

Macroautophagy, here referred to as autophagy, is a conserved endolysosomal cellular mechanism that coordinates the engulfment of cytoplasmic material into autophagosomes. Autophagosomes are fated to degradation and recycling after lysosomal fusion, forming the autolysosomes [26]. The acidic component of the lysosomes and autolysosomes is essential for the digestion of cargo originated from endocytosis, macropinocytosis, and autophagosomes. Thus, autophagy interacts with the endosomal pathway of the lysosomes [27] and plays critical roles in several physiological and pathological conditions, including cell survival and death, aging, metabolism, immunity and infection [28-33].

Autophagy is triggered by the inhibition of mammalian target of rapamycin complex 1 (mTORC1), the primary regulator of nutrient signaling. It has been demonstrated that mTORC1 integrates various stimuli and signaling networks to promote anabolic (e.g., protein synthesis) and inhibit catabolic (e.g., autophagy) processes [34]. Moreover, the mTORC1 complex is modulated by upstream regulators that transduce growth factors and energy signals. For example, stimulation of the phosphoinositide 3-kinase/serine-threonine kinase (PI3K/AKT) activates mTORC1 [35,36], while the adenosine monophosphateactivated protein kinase (AMPK), a sensor of cellular energy levels, inhibits the activity of mTORC1 [37]. Upon activation, mTORC1 inhibits downstream Netrin receptor (Uncoordinated protein 5) (UNC-5) effectors, such as the ULK1 (Unc-51 like autophagy activating kinase 1) complex, which phosphorylate the autophagy initiation machinery, including the autophagy-related protein 13 (Atg13) and ULK1 [38,39].

Autophagosome formation and its self-assembly are coordinated by enzymes and proteins located in the ER, such as phosphatidylinositol 3-phosphate (PI3P) and B-cell lymphoma 2 (BCL-2) interacting proteins Beclin-1/vacuolar protein sorting 34 (Beclin$1 /$ Vps34) complex [40,41]. In addition to these proteins, the activating molecule in Beclin1-regulated autophagy (Ambra1) plays a vital role as a regulator of autophagy, binding to Beclin-1, promoting the autophagosome formation [42]. The stabilization of the Beclin$1 / \mathrm{Vps} 34$ complex and initiating interaction among these autophagy regulators leads to the formation of PI3P and the recruitment of WD repeat domain phosphoinositide-interacting protein (WIPI) proteins to the autophagosome membrane. It has been reported that the conjugation of WIPI $2 \mathrm{~b}$ to PI3P promotes the lipidation of microtubule-associated proteins $1 \mathrm{~A} / 1 \mathrm{~B}$ light chain $3 \mathrm{~A}$ (LC3) and the elongation of the membrane [43]. In the autophagosome inner membrane, LC3-II, a mammalian homolog of Atg8 in yeast, plays a vital role in selfassembly, elongation and closure of the DMVs [44], which upon autophagy activation, a phosphatidylethanolamine is added to cytoplasmic LC3-I forming LC3-II, which translocate to the membrane [45]. LC3-II remains on the autophagosome membrane until fusion with acidic lysosomes, resulting in the formation of autolysosomes and completion of the degradation process (autophagic flux) [44]. While the fusion of the autophagosome with the lysosome is not fully understood, evidence suggests that specific membrane fusion proteins, called N-ethylmaleimide-sensitive factor attachment protein receptor (SNARE) complexes, participate in this process. Additionally, autophagosome-lysosome fusion is mediated by the interaction of Syntaxin 17 (Stx17), present in the external membrane of the autophagosome, with synaptosome-associated protein 29 (SNAP29) and vesicle-associated membrane protein 8 (VAMP8), both localized to the lysosome, consequently promoting the membrane fusion and subsequent cargo degradation [46].

Components of the autophagy machinery also participate in the secretion of invading pathogens. For example, poliovirus uses LC3-positive DMVs to escape the host cell defenses via a secreted autophagosome coated with the cellular components of the host, enabling a non-lytic release of virions [47,48]. Indeed, multiple viruses have evolved strategies to avoid host virophagic responses, including the expression of Beclin-1 inhibitors [49,50], 
proteins that inhibit the fusion of autophagosomes with lysosomes [51,52] and miRNA targeting autophagy and type 1 interferon signaling [53].

The use of autophagic machinery by CoVs was demonstrated, where the initiation of vesicle formation was inhibited by knocking out autophagy-related gene 5 (ATG5) or by wortmannin, suggesting that nsp6-induced autophagy was dependent on Atg5 and PI3K. Finally, transfecting the SARS-CoV open reading frame $-8 \mathrm{~b}$ and $-3 \mathrm{a}$ into $293 \mathrm{~T}$ and HeLa cells triggers lysosomal damage and ER stress, consequently inducing the translocation of Transcription Factor EB (TFEB) to the nucleus, a master regulator of lysosomal biogenesis and favoring the transcription of autophagy- and lysosome-related genes $[54,55]$.

Defects in the molecular machinery for macroautophagy, such as the genetic inhibition of ATG5 or beclin-1 (BECN1) genes, consequently make mice and primary human astrocytes more susceptible to viral infections [56-58]. Efficient virophagic responses also involve p62 and Atg5 [56]. Conversely, human immunodeficiency virus (HIV)- $1^{+}$patients who remained clinically stable for years in the absence of therapy display higher amounts of autophagic vesicles and high expression of autophagic markers in the peripheral blood mononuclear cells [59].

Conversely, other studies have highlighted the inhibitory effects of $\mathrm{CoV}$ nonstructural proteins on autophagy flux. In fact, overexpressing CoVs membrane-associated papain-like protease PLP2 (PLP2-TM) resulted in inhibition of autophagosome-lysosome fusion and blockade of autophagic flux in HEK293T, HeLa and MCF-7 cells [52]. Likewise, recent evidence described that Vero B4 cells infected with MERS-CoV exhibited reduced Beclin-1 levels, enhanced K48-polyubiquitylation of Beclin-1, reduced Atg14 oligomerization and blocked autophagosome-lysosome fusion [60]. Correspondingly, temporal kinome analysis of Huh7 and MRC5 cells infected with MERS-CoV displayed upregulated $\mathrm{PI} 3 \mathrm{~K} / \mathrm{AKT} / \mathrm{mTOR}$ and extracellular signal-regulated kinase/mitogen-activated protein kinase (ERK/MAPK)-mediated signaling [61]. Moreover, the double-stranded DNA human papilloma virus (HPV) promotes the inhibition of autophagy in infected host cells [62]. Mechanistically, HPV invasion and infection cause the stimulation of PI3K/AKT/mTOR pathway, increasing protein synthesis and reducing autophagy [63]. Additionally, HPV infection reduces many genes related to autophagy, including beclin-1 gene (BECN1) [64]. On the other hand, RNA viruses such as influenza A [65], porcine parvovirus [66], enterovirus A71 [67], dengue virus [68] and Zika virus [69], induce autophagy to help with their replication, and avoid recognition and degradation through autophagy. The mechanism includes inhibition of translocation of Stx17 and SNARE proteins, compromising autophagosome-lysosome fusion, and proteases that cleaves sequestosome-1 (SQSTM1) to prevent detection of viral target [70]. Overall, several studies have reported that the regulation of autophagy upon viral infection depends on factors related to the virus and the host cell, as also reviewed by Chiramel et al., (2013) [71].

An in-depth analysis of autophagy signaling, and metabolomics corroborated the notion that CoVs modulate PI3K/AKT/mTOR and AMPK signaling, showing that SARS$\mathrm{CoV}-2$ reduced glycolysis and protein translation by limiting the activation of mTORC1 and AMPK. It was shown that SARS-CoV-2 infection also downregulated spermidine and facilitated AKT1/S-phase kinase-associated protein 2 (SKP2)-dependent degradation of Beclin-1 [72]. Additionally, in particular, viral xenophagy (virophagy), an autophagic response directed to fully formed cytoplasmic virions or viral components [73], helps direct the virus to degradation, by presenting antigens and recognizing viruses, thus regulating inflammation and releasing proinflammatory cytokines [74]. Finally, some studies challenge the notion that virus replication depends on the autophagy proteins of the host. In fact, it was previously shown that ATG5 or ATG7 are not required for mouse hepatitis virus [75,76] or SARS-CoVs [77] replication, since knocking out of these genes did not inhibit viral infection.

Since autophagy may be one of the molecular mechanisms that allow cell invasion and virus replication, it is possible that some mutations may alter the autophagic process [78,79]. SARS-CoV-2, like any type of virus, accumulates mutations over time, and most of these 
mutations do not implicate in biological effects. However, some key mutations can alter viral biology to the extent of causing changes in its transmission and infection capacity [80]. Although SARS-CoV-2 does not have a high mutation rate (less than 25 predicted mutations per year), effectively identifying and tracking these mutations is of paramount importance for defining epidemiological parameters, and monitoring the evolution of the pandemic $[80,81]$. To this end, the genomic surveillance is currently carried out using several tools to identify these mutations, such as genomic and interatomic analysis web tools, phylogenetic analysis and the use of the network-based genetic divergence studies, which provide information to identify possible characteristics related to drug resistance and vaccine evasion $[80,82,83]$.

Benvenuto et al., (2020) described mutations that affect the non-structural protein 6 (Nsp6), a protein encoded by the CoVs genome that binds to the host's ER, promoting the generation of autophagosomes $[79,84]$. These mutations, in theory, should favor the affinity of the nsp6 protein with the ER, allowing a more stable binding between these components [79]. It is known that this binding favors viral infection, since it compromises the function of autophagosomes to deliver viral components for degradation in the host's lysosomes $[79,84]$. However, the authors emphasize the need for more studies that can prove this interaction [79]. Additionally, in December of 2020, a preprint was published stating that one of the most relevant mutations in SARS-CoV-2, described as D614G, can increase the lysosomal traffic of the virus spike in infected cells, accelerating its process of entry into uninfected cells. The authors postulate that this is a possible explanation for the higher rates of transmission and infectivity promoted by this mutation [85]. New strains and clades of SARS-CoV-2 will emerge over time and some might eventually be resistant to drugs and vaccines that are currently being used or developed. However, currently available data demonstrate that the identified mutations so far did not alter the structure of the virus enough to create mechanisms to evade existing vaccines [86,87].

More recently, interactome studies revealed extra or intracellular interactions between SARS-CoV-2 proteins, not only Spike, and the host cell, involving endocytosis, autophagy and signaling. In a SARS-CoV-2 RNA interactome study from Huh7 cells, researchers observed 12 translation factors $24 \mathrm{~h}$ after infection [88]. Among them, components eukaryotic translation initiation factor Gamma 1 and 4B, respectively, EIF4G1, EIF4B, from the components eukaryotic translation initiation factor $4 \mathrm{~F}$ (EIF4F), which is known to control mTOR activity [88]. This study also showed several interactors associated to vesicle trafficking proteins, such as SCFD1, USO1, RAB1A, RAB6D, RAB6A, RAB7A and GDI2 [88]. Additionally, Gordon et al., (2020) observed 332 protein interactions between SARS-CoV-2 and human proteins, among them, also proteins associated to vesicle traffic, such as Nsp6, Nsp7, Nsp10, Nsp13, Nsp15, open-reading frame 3a (Orf3a) and 8 (Orf8) [89].

Furthermore, Kliche et al., (2021) observed that the LC3-interacting region (LIR) in integrin $\beta 3$ binding to the Atg8 domains of the autophagy receptors microtubuleassociated protein 1A/1B-Light Chain 3 (MAP1LC3) MAP1LC3 and gamma-aminobutyric acid receptor-associated protein (GABARAP) in an enhanced manner by LIR-adjacent phosphorylation [90]. However, LC3 or green fluorescent protein (GFP)-LC3 failed to colocalize with viral replication-transcription complexes in SARS-CoV-infected Vero cells [91]. Thus, it appears as though non-canonical autophagy and/or unique components of the autophagy machinery are sequestered regardless of their activity in autophagic processing, which would mediate the induction of autophagy during CoVs infection [92]. These findings strongly support the idea that CoVs bypass autophagy to promote their replication. In fact, activation of autophagy and the endocytic pathway seems to play an important role in cell invasion and viral replication of CoVs, providing strong evidences for pharmacological targets development. However, gaps in knowledge are yet to be settled, as pointed and previously reviewed by Yang and Shen (2020) [78].

Briefly, Table 1 summarizes the molecular machinery recruited in autophagy initiation and Figure 1 shows that autophagy mechanisms represent potential targets for pharmacological inhibition of CoVs infection and replication. 
Table 1. Molecular machinery recruited in autophagy initiation.

\begin{tabular}{|c|c|c|c|}
\hline Acronym & Protein & Function & Ref. \\
\hline \multicolumn{4}{|c|}{ 1. Transcriptional factors } \\
\hline TFEB & Transcription factor EB & $\begin{array}{l}\text { A master gene regulator of lysosomal biogenesis } \\
\text { and autophagy }\end{array}$ & {$[54,55]$} \\
\hline \multicolumn{4}{|c|}{ 2. Initiation of autophagy } \\
\hline mTORC1 & Mammalian target of rapamycin complex 1 & $\begin{array}{l}\text { Nutrient sensor and controller of protein synthesis } \\
\text { and autophagy }\end{array}$ & [34] \\
\hline \multicolumn{4}{|c|}{ 3. Upstream regulators of mTORC1 } \\
\hline $\mathrm{AKT}$ & Serine-threonine kinase & $\begin{array}{l}\text { Cell growth, proliferation, differentiation and } \\
\text { survival signalling }\end{array}$ & {$[35,36]$} \\
\hline AMPK & $\begin{array}{l}\text { Adenosine monophosphate-activated } \\
\text { protein kinase }\end{array}$ & Energy homeostasis signalling & [37] \\
\hline BCL-2 & B-cell lymphoma 2 & Regulation of cell death & {$[40,41]$} \\
\hline ERK/MAPK & $\begin{array}{l}\text { Extracellular signal-regulated } \\
\text { kinase/mitogen-activated protein kinase }\end{array}$ & Regulation of cell proliferation & [61] \\
\hline PI3K & Phosphoinositide 3-kinase & $\begin{array}{l}\text { Cell growth, proliferation, differentiation and } \\
\text { survival signalling }\end{array}$ & {$[35,36]$} \\
\hline \multicolumn{4}{|c|}{ 4. Nucleation and phagophore formation } \\
\hline Ambra1 & $\begin{array}{l}\text { Activating molecule in Beclin-1-regulated } \\
\text { autophagy }\end{array}$ & Positive regulator of Beclin-1-mediated autophagy & [42] \\
\hline BECN1 & Beclin-1 & Regulator of autophagic programmed cell death & {$[40,41]$} \\
\hline ULK1 & Unc-51 like autophagy activating kinase & Autophagy initiator & {$[38,39]$} \\
\hline \multicolumn{4}{|c|}{ 5. Autophagosome formation and elongation } \\
\hline Atg & Autophagy-related protein & $\begin{array}{l}\text { Factors required for the formation of } \\
\text { autophagosomal membranes }\end{array}$ & [34] \\
\hline LC3 & $\begin{array}{l}\text { Microtubule-associated proteins 1A/1B light } \\
\text { chain 3A }\end{array}$ & $\begin{array}{l}\text { Autophagosomal marker that mediates the } \\
\text { physical interactions between microtubules and } \\
\text { components of the cytoskeleton }\end{array}$ & [43] \\
\hline p62/SQSTM1 & $\begin{array}{l}\text { Ubiquitin-binding protein } \\
\text { p62/Sequestosome-1 }\end{array}$ & $\begin{array}{l}\text { An autophagosome cargo protein that targets and } \\
\text { labels other proteins for selective autophagy }\end{array}$ & {$[56,70]$} \\
\hline Vps34 & Vacuolar protein sorting 34 & $\begin{array}{l}\text { A class III phosphoinositide 3-kinase that acts on } \\
\text { vesicle trafficking }\end{array}$ & [43] \\
\hline WIPI2 & $\begin{array}{l}\text { WD repeat domain } \\
\text { phosphoinositide-interacting protein proteins }\end{array}$ & Regulates the assembly of multiprotein complexes & [43] \\
\hline \multicolumn{4}{|c|}{ 6. Autophagosome-lysosome fusion } \\
\hline SNAP29 & Synaptosome-associated protein 29 & Mediates autophagosome-lysosome fusion & [46] \\
\hline SNARE & $\begin{array}{l}\text { N-ethylmaleimide-sensitive factor attachment } \\
\text { protein receptor complexes }\end{array}$ & Vesicle fusion mediator & {$[46,70]$} \\
\hline Stx17 & Syntaxin 17 & $\begin{array}{l}\text { A SNARE like protein that mediates } \\
\text { autophagosome-lysosome fusion }\end{array}$ & {$[46,70]$} \\
\hline VAMP8 & Vesicle-associated membrane protein 8 & $\begin{array}{l}\text { A SNARE like protein that mediates } \\
\text { autophagosome-lysosome fusion }\end{array}$ & [46] \\
\hline
\end{tabular}




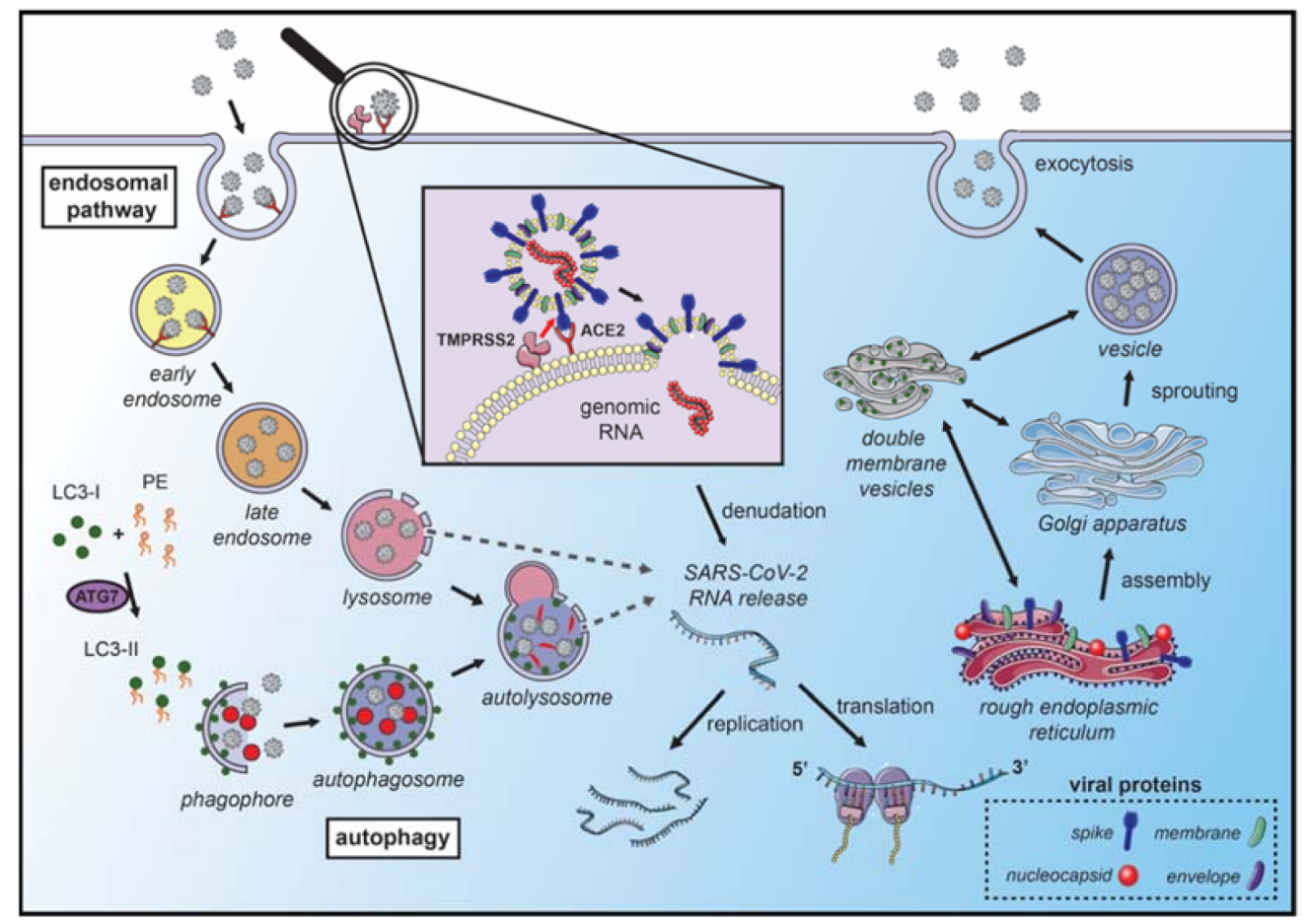

Figure 1. Coronavirus hijacks autophagy machinery to promote their replication. SARS-CoVs bind to the angiotensin-converting enzyme 2 (ACE2) receptor on the membrane surface and enter the host cell. The fusion with the membrane and the release of the genomic RNA into the cytoplasm occurs after the cleavage of the spike (S) protein, which can occur in several locations. S protein cleavage occurs on the cell membrane surface by the transmembrane protease serine 2 (TMPRSS2), which is associated with the ACE2 receptor, or by cathepsin-L and cysteine proteases in the endosomal system. The acidic $\mathrm{pH}$ in the lysosomes is necessary for the activity of cathepsin- $\mathrm{L}$ and $\mathrm{S}$ protein cleavage. Next, the endosomal cargo converges with the autophagic vacuoles in the lysosomes. Coronavirus nonstructural proteins colocalize with microtubule-associated proteins 1A/1B light chain 3A (LC3-II) in the endomembrane system, suggesting that autophagy plays a role in amplifying coronavirus replication. After fusion with the membrane, the genomic RNA is released and stripped of the nucleocapsid protein. Viral proteins are translated in the endoplasmic reticulum, which promotes the rearrangement of endoplasmic reticulum membranes and the formation of double-membrane vesicles, which are also localized with LC3 and autophagy-related proteins. The newly synthesized genomic RNA is then assembled into virions in intermediate compartments located between the endoplasmic reticulum and the Golgi apparatus and moves through the secretory pathway of the host and eventually released by exocytosis (the illustration was produced using the smart servier medical art vectors for publications and presentations licensed under the Creative Commons (CC BY 3.0)) [93].

\section{Autophagy-Related Therapeutic Targets for COVID-19 Management}

The network of endosomal-autophagic vesicles appears to play a central role in CoVs infection, including SARS-CoVs $[60,78,94]$. It is known that autophagy plays a role in pulmonary infections, enhancing the immune defenses of host against viral and bacterial infections of respiratory tract $[95,96]$. Considering the different roles autophagy plays during viral infection [97-99], we postulate that three groups of autophagy modulators could inhibit viral replication and are clinically relevant to COVID-19. The first group consists of drugs with lysosomotropic properties, which inhibits cathepsin activity and could prevent CoVs infection by neutralizing the acidic $\mathrm{pH}$ of the endosomes-lysosomes [100]. The second group is composed of protease inhibitors, which could inhibit the proteolytic cleavage of the $S$ protein and consequently restrict viral cell entry [101]. The third group contains $\mathrm{PI} 3 \mathrm{~K} / \mathrm{AKT} / \mathrm{mTOR}$ regulators that, although considered autophagy regulators, 
could prevent the CoVs-mediated appropriation of the autophagic machinery [102,103]. In the following subsections, we will discuss several clinically approved and well-tolerated autophagy-modulating compounds that could be explored as potential modulators of SARS-CoV-2 infection and replication for the management of COVID-19.

\subsection{Lysosomotropic Agents}

4.1.1. Chloroquine and Hydroxychloroquine

Chloroquine (CQ) and hydroxychloroquine (HCQ) are weak diprotic bases used as antimalarial drugs (Figure 2). These compounds accumulate in the endosome-lysosomal network of cells and neutralize the acidic $\mathrm{pH}$, with consequent blockage of cathepsin activity and lysosomal fusion $[104,105]$. Previous studies showed that CQ displays a widespectrum of antiviral effects against $\mathrm{CoVs}$, chronic $\mathrm{HIV}$, and influenza viruses type $\mathrm{A}$ and B, both in vitro and in vivo [106,107].

Recent in vitro evidence, employing kidney-derived Vero cells, has indicated that CQ/HCQ could be effective at controlling the COVID-19 pandemic [108]. Indeed, several clinical trials investigating the efficacy of CQ/HCQ were initiated [109]. However, it should be pointed out that a recent study reported that the engineered expression of TMPRSS2 in Vero cells attenuates CQ-mediated antiviral activity, suggesting that SARS-CoV-2 infection may occur through multiple mechanisms [110].

Furthermore, a recent review on the use of CQ/HCQ for the treatment of COVID19 with a small number of patients showed positive results in the recovery of infected patients. However, data from a study with a larger number of patients did not reveal any significant improvement in the symptoms of the disease. Instead, they highlighted the potential hazards to the health of the patients due to dangerous side effects [111], including retinopathy and increased waves QT interval in the electrocardiogram [112].

Additionally, on 15 June 2020, the FDA revoked the use of HCQ/CQ for COVID19 treatment [113]. Then on 17 June 2020, the WHO announced that the HCQ arm of the solidarity trial for potential COVID-19 therapies would be discontinued [114]. Both of these actions were in response to the Randomised Evaluation of COVID-19 Therapy (RECOVERY) trial report conducted by Oxford University on patients from National Health Service (NHS) hospitals in the United Kingdom published on 5 June 2020. The chief investigators stated that a randomized trial, with a total of 1542 patients treated with HCQ compared to 3132 patients under usual care, found no significant differences in the mortality endpoint $(25.7 \%$ HCQ vs. $23.5 \%$ usual care), hospital stay duration or any other outcome [115].

The FDA memorandum also reviewed other randomized, open-label and retrospective studies and highlighted that the results regarding differences in viral RNA shedding, when comparing HCQ/CQ-treated patients with others who did not receive these medications, were inconsistent. Thus, the FDA concluded that it is no longer reasonable to believe that the oral formulations of HCQ/CQ were effective at treating COVID-19 [113].

Nonetheless, it is plausible that the mechanistic insights related to the CQ/HCQ mode of action could lead to the development of safer and more effective COVID-19 therapies [100]. For example, in vitro studies showed that CQ induced intracellular retention of ACE2 and abrogated the SARS-CoV-2-receptor binding at the cell surface and cellular entry [116]. Similarly, cell cultures treated with $\mathrm{CQ}, \mathrm{NH}_{4} \mathrm{Cl}$ or bafilomycin A1 (an endo/lysosomal V-ATPase inhibitor) resulted in ACE2 receptor arrest within the perinuclear vacuoles, suggesting that lysosomotropic agents may share pharmacological targets [117]. Nonetheless, the lysosomotropic agents could interfere in the ACE2 action, avoiding the viral invasion and entry in host cells, since this entry route constitute an important pathway for viral invasion and cell infection [78]. In fact, recent studies have demonstrated that drugs with mechanistic similarity to $\mathrm{CQ} / \mathrm{HQC}$ revealed inhibitory activity against SARS-CoV-2. For instance, GNS561, a small basic lipophilic molecule that induces lysosomal dysregulation and inhibition of the late-stage of autophagy, demonstrated potent in vitro antiviral activity against the novel SARS-CoV-2 alone and in com- 
bination with remdesvir [118]. Currently, GNS561 is being tested in cancer patients with moderate COVID-19 (National Institute of Health (NIH)-Clinical Trials Database; Identifier: NCT04333914) [119]. A recent study found that four lysosomotropic autophagy-inhibiting compounds-namely ROC-325, mefloquine, hycanthone and clomipramine-blocked the cytopathic effect of SARS-CoV-2 in Vero-E6 cells [120]. Moreover, the cytopathic effect against the SARS-CoV-2 correlated with LC3 puncta in antiviral doses [120]. Nonetheless, taken together, the current evidence discards HCQ/CQ as a repurposed treatment with potential to manage COVID-19 [115].

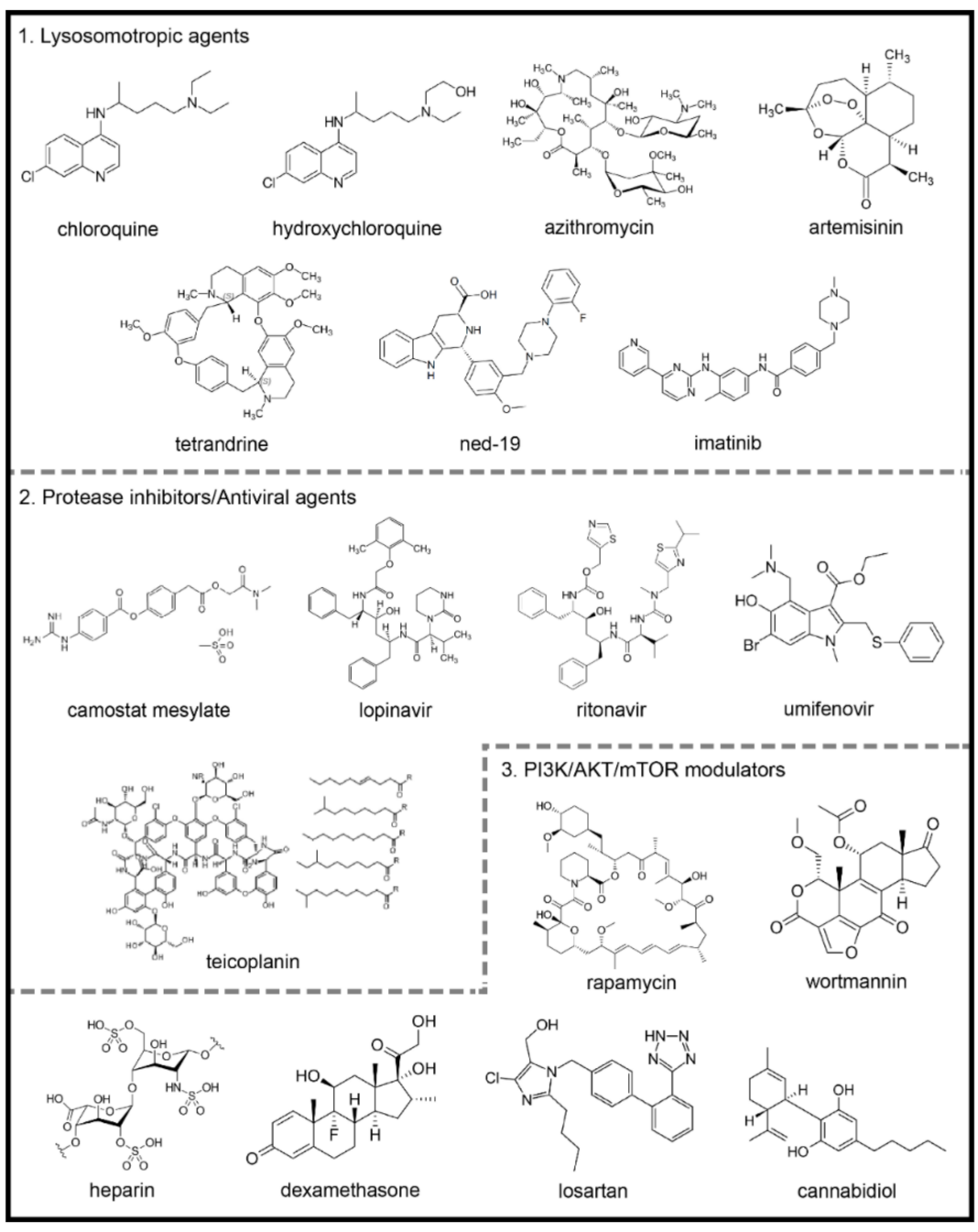

Figure 2. Chemical structures of potential autophagy-related drugs for SARS-CoV-2 infection. The drugs were divided in three groups according to their effects on the autophagy signaling pathway and possible effect against SARS-CoV-2 infection. The lysosomotropic agents (1) can prevent coronavirus infection by alkalinizing the acid $\mathrm{pH}$ in the endolysosomal system; some examples are chloroquine, hydroxychloroquine, azithromycin, artemisinin, two-pore channel antagonists (such as tetrandrine and ned-19) and imatinib. The protease inhibitors/antiviral agents (2) can inhibit the proteolytic cleavage of the spike coronavirus protein, which is necessary for viral entry into host cells; some examples are camostat mesylate, lopinavir, ritonavir, umifenovir and teicoplanin. The third group is composed by PI3K/AKT/mTOR signaling pathways modulators (3), which can modulate intracellular pathways related to autophagy and coronavirus infection; some examples are the rapamycin, wortmannin, the anticoagulant heparin, the glucocorticoid dexamethasone, losartan and cannabidiol. The figures for each chemical structure are from according to Wikimedia Commons (Public Domain). 


\subsubsection{Azithromycin}

Azithromycin is a broad-spectrum macrolide antibiotic that binds to the S50 ribosomal subunit of bacteria inhibiting its protein synthesis [121] (Figure 2). The antiviral efficacy of azithromycin has been demonstrated in different viral infections [122-125]. For example, in 2019, an in vitro study evaluated azithromycin against influenza A (H1N1) infection and found that it blocks the cellular internalization of the virus and inactivates its endocytic activity [125]. More recently, a study using respiratory epithelial cells of cystic fibrosis showed that azithromycin has an antiviral action similar to HCQ, acting as a weak acidophilic lipophilic base and increasing the $\mathrm{pH}$ of organelles such as the endosome and the trans-Golgi [126].

Interestingly, other studies have reported synergism between HCQ and azithromycin in the treatment of SARS-CoV-2 infections $[127,128]$. This recommendation is based on recent in vitro data showing that azithromycin and CQ cotreatment reduces SARS-CoV2 replication [127]. Notably, clinical trials with this drug combination have been conducted [129-132], but the available data are divergent and inconclusive [133,134]. Of note, the conclusions made by Gautret et al., (2020) have been considered by Nguyen et al. (2021) as not based on a rigorous study design or analysis, being the effect of HCQ and azithromycin on antiviral effect remaining uncertain. Additionally, there are risks of secondary effects of this treatment, such as heart complications $[130,132]$. Thus, for now, there is no significant benefit of azithromycin, or its association with CQ/HCQ, for the treatment of COVID-19.

\subsubsection{Artemisinin and Its Derivative Compounds}

Artemisinin is isolated from the herb Artemisia annua L. [135]. The derivative compounds are sesquiterpene lactones with a unique endoperoxide bridge moiety primarily responsible for their biological actions [136] (Figure 2). The compounds target several signaling pathways involved in the inhibition of autophagy, due the lysosomal disruption, release of cathepsins and other hydrolytic enzymes into the cytosol and subsequent cell death [137].

Studies have also demonstrated that, in cancer cells, artemisinin and its derivatives regulate proteins involved in several autophagy signaling pathways. Guan and Guan (2020) showed autophagosomes visualization, a hallmark of autophagy, in cancer cells exposed to artemisinin [138]. Additionally, these compounds inhibit mTOR, nuclear factor kappa B (NF-KB), PI3K and the signal transducer and activator of transcription 3 (STAT3) [136].

Traditionally, artemisinin was used for fever treatment and recently it has been approved as a therapy for malaria [139]. Previous data showed that artemisinin complexes are effective against viral infections, such as human cytomegalovirus (HCMV), human herpes simplex virus 1 and 2 (HSV-1 and HSV-2), hepatitis C virus (HCV), hepatitis B virus (HBV), HPV 39 and polyomavirus BK [140]. Moreover, artemisinin modulates inflammatory and immunologic responses in doses that are relatively safe, with a low toxicity profile [141]. Concerning the anti-inflammatory properties, artemisinin regulates the expression of pro and anti-inflammatory cytokines (e.g., IL-1 $\beta$, IL-2, IL-6, IL-8 and IFN- $\gamma$ ) and NF-kB, and has been used to treat different respiratory diseases [142]. The regulation of NF- $\kappa B$ expression is of particular importance since its inhibition decreased the severity of the acute respiratory syndrome and increased the survival of SARS-CoV infected mice [143]. These data suggest that artemisinin and related compounds may show interesting results against SARS-CoV-2 infections.

At the moment, ArtemiC, a micellar formulation of artemisinin, curcumin, frankincense (Boswellia) and vitamin C, which is administered by spraying, is in phase II of clinical trials for patients diagnosed with COVID-19 (NIH-Clinical Trials Database; Identifier: NCT04382040 and NCT04553705) [119]. Additionally, another phase II clinical trial investigates the effects of artemisinin/artesunate on the course of the disease and viral load is currently underway in patients with COVID-19 (NIH-Clinical Trials Database; Identifier: NCT04387240) [119]. So far, no clinical evidence is available as none of the studies are 
yet concluded, but a very recent preprint study demonstrated anti-SARS-CoV-2 activity in vitro of three artemisinin compounds: artesunate, arteannuin B and lumefantrine [144].

\subsubsection{Two-Pore Channels Modulating Agents}

Nicotinic acid adenine dinucleotide phosphate (NAADP) is an intracellular messenger that plays a vital role in the mobilization of $\mathrm{Ca}^{2+}$ in mammalians cells [145-148] by binding to two-pore channels (TPCs) $[149,150]$. Furthermore, NAADP has been reported as a potent $\mathrm{Ca}^{2+}$ mobilizing messenger and inducer of autophagy [151-156]. On the other hand, the TPC antagonists ned-19 and tetrandine (Figure 2) were postulated as possible blockers of lysosomal function, causing a further inhibition of autophagy on the degradation step [152].

Interestingly, TPCs have been identified as a new host factor for Ebola virus (EBOV) entry, and their inhibition prevents EBOV infection [157,158]. Similarly to CoVs, EBOV enters the host cell and moves through the endolysosomal system, using the cell machinery of the host for its replication and releasing its genome into the cytoplasm [159]. Moreover, TPC1 or TPC2 colocalize with MERS-CoV S protein in Huh7 cells, providing evidence that TPCs may also regulate MERS-CoV viral entry [160]. In this study, the authors observed that several $\mathrm{Na}^{+}$channel blockers and voltage-operated $\mathrm{Ca}^{2+}$ antagonist drugs, including ned-19 and tetrandrine, attenuated MERS-CoV translocation in Huh7 cells. Moreover, the complete inhibition of $\mathrm{Ca}^{2+}$ release was not related to lysosomotropism, and no alterations in lysosomal $\mathrm{pH}$ were detected after applying these drugs. Thus, based on the fact that stimulation of the transient receptor potential mucolipin 1 (TRPML1) failed to control MERS-CoV pseudovirus infectivity, it was concluded that the TPC function might be required for this infection [160]. These findings suggest that TPC activity is essential for the passage of EBOV and MERS-CoV virus through the endolysosomal trafficking pathway, and that $\mathrm{Ca}^{2+}$ channel ligands might hinder viral infectivity. Currently, the only clinical trial employing tetrandrine (approved for Clinical Trials for COVID-19, NIHClinical Trials Database, 2020; Identifier: NCT04308317) [119] is still recruiting and not yet concluded, refraining any conclusion about clinical efficacy. Thus, understanding the role that TPCs play in viral infectivity could lead to the discovery of novel antiviral agents, maybe against SARS-CoV-2.

\subsubsection{Imatinib}

Imatinib, a tyrosine kinase inhibitor developed in 2001, revolutionized the treatment of chronic myeloid leukemia [161], since its activity against the breakpoint cluster region gene-Abelson proto-oncogene (BCR-ABL) in cancerous cells [162] (Figure 2).

Several ongoing studies are exploring imatinib in other pathologies that are associated with its target kinases. For example, García et al., (2012) proposed that imatinib could inhibit EBOV replication and release by blocking c-ABL1 and VP40 phosphorylation [163]. In addition, preclinical data demonstrated that imatinib inhibits the fusion MERS-CoV and impairs endosomal trafficking in vitro [164]. Since the ABL-2 activity is essential for sequential steps involving fusion to viral replication, its inhibition by imatinib leads to impaired replication of SARS-CoV and MERS-CoV in vitro [162,165].

Concerning COVID-19, Morales-Ortega et al., (2020) administered imatinib (400 mg/day) to a SARS-CoV-2 infected patient who was progressing to a severe inflammatory state after 12 days of symptoms [166]. After three days of treatment with imatinib, the fever disappeared, oxygen supplementation was interrupted and the radiological stability of pulmonary opacities was confirmed. There was also an improvement in laboratory parameters after the 5th day of treatment [166]. Currently, there are four ongoing clinical studies (phase II/III) with imatinib being conducted in accordance with the NIH (NCT04394416, NCT04422678, NCT04346147 and NCT04357613). Such clinical trials are testing the efficacy of this drug alone, or in combination with other drugs, in the treatment of COVID-19 (NIH-Clinical Trials Database) [119]. So far, no clinical evidence is available as studies are under recruitment stage and not yet concluded. The results of these studies will provide a scientific basis for this pharmacological application. 
Taken together, CQ/HCQ alone or in combinations with macrolides failed as an antiviral, immunomodulatory or prophylactic therapy against COVID-19 [115], but other lysosomotropic agents, such as imatinib, remains as promising strategies [167-169]. Sauvat et al., (2020) discuss SARS-CoV-2-inhibiting lysosomotropic agents as "on-target" versus "off-target" and presents a rationale for their clinical application. Briefly, "off-target" agents display unspecific action upon acidophilic organelles including autophagosomes, endosomes and lysosomes, with CQ/HCQ as the prototypical example for the class. The non-specific effects of "off-target" agents result in amplified safety issues related to side effects versus antiviral activity ratio. Thus, clinical trials conducted with these drugs are expected to fail due to low efficacy and safety [170]. In contrast, "on-target" agents mediate their effects through specific mechanism, which results in reduced side-effects and increased therapeutic index. For instance, imatinib has demonstrated few side effects in the long-term treatment of chronic myeloid leukemia [171] and gastrointestinal stromal tumors [172]. Thus, the pursuit for lysosomotropic agents should focus on agents with a well-defined therapeutic target in order to enhance a therapeutic index and raise drug efficacy and safety against COVID-19.

\subsection{Protease Inhibitors/Antiviral Agents: The Prevention of Infection}

\subsubsection{Camostat Mesylate}

Camostat mesylate inhibits the serine protease TMPRSS2 and prevents the entry of SARS-CoV-2 into the host cells [101] (Figure 2). Other proteases, including cathepsin-L, thermolysins, plasmins and trypsin, can act as a cofactor for virus entry into the host cell [173]. In this sense, strategies that target the inhibition of TMPRSS2 activity could block SARS-CoV-2 cell invasion and potentially hinder autophagy machinery appropriation by SARS-CoV-2 virions [174]. Indeed, in vitro and in vivo studies have described the inhibitory effect of camostat mesylate on SARS-CoV invasion and infection.

In mice, Zhou et al., (2015) demonstrated that camostat mesylate was effective against SARS-CoV infection, reducing the pathogenesis and increasing the survival rate of animals exposed to the virus. The same authors also suggested that similar results might be observed with MERS-CoV infections [175]. Furthermore, in vitro studies performed by Hoffmann et al., (2020) showed that camostat mesylate-mediated inhibition of TMPRSS2 reduced SARS-CoV-2 entry and infection of the human lung Calu-3 cell line [101]. According to the NIH (NIH-Clinical Trials Database) [119], fourteen clinical trials are recruiting and will investigate the efficacy of camostat mesylate, alone or in combination with other drugs, in patients with COVID-19. One of these studies was withdrawn due to lack of public funding and evidence as the planned control arm with HCQ treatment showed out as not being standard of care anymore as time evolved (NCT04338906).

\subsubsection{Lopinavir}

Lopinavir (ABT-378) is a potent protease inhibitor used to prevent HIV replication and spread [174] (Figure 2). It has been suggested that since SARS-CoV-2 contains structural components that are similar to other viruses, including HIV, it is plausible that this antiviral therapy could be used to treat patients with COVID-19 [176].

The administration of lopinavir/ritonavir to marmosets infected with MERS-CoV demonstrated that it could reduce the disease progression and improved clinical outcomes [177]. In a randomized, controlled, open-label trial conducted in Wuhan (China), 199 patients with COVID-19 were treated with lopinavir/ritonavir (400 mg/100 mg) twice a day for 14 days in combination with standard care treatment or standard care treatment alone [178]. Results showed that drug-treated patients did not demonstrate clinical improvement or reduced mortality after 14 days. Additionally, the drug combination failed to attenuate the viral RNA load, which was assessed in patients at the end of the trial.

At the moment, more than eighty clinical trials are registered on the NIH website with lopinavir/ritonavir or in combination with ribavirin or interferon $\beta 1 \mathrm{a}$ are in the initial phases or ended (NIH-Clinical Trials Database; Identifier: NCT04276688) [119]. Results 
of the concluded studies are not available yet, restraining any clinical conclusion, while withdrawn studies occurred only due to epidemiological dynamics and lack of funding.

\subsubsection{Umifenovir}

Umifenovir is currently used in Russia and China as a prophylaxis for the treatment of pulmonary infections caused by human influenza A and B viruses and HCV $[179,180]$ (Figure 2). The proposed mode of action of umifenovir involves intercalation with membrane lipids, inhibiting viral fusion with the plasma membrane of the host cell. It has also been shown that the drug can bind to the membrane-bound clathrin protein and prevent endocytosis of the virus [179]. It has been suggested that umifenovir may be effective against EBOV and Lassa virus, highly pathogenic agents that caused outbreaks in the West African region [181,182]. Additionally, in vitro studies demonstrated that umifenovir displays antiviral activity against the SARS-CoV viruses [183].

Considering that umifenovir binds directly to membrane phospholipids and endosomal vesicles, it could interfere with the autophagic flux of the host cell. However, there have been no studies linking the action of the drug with autophagy. Based on these results discussed above, umifenovir is a promising drug against CoVs. Currently, ongoing randomized clinical trials evaluating the efficacy and safety of umifenovir against COVID-19 are being conducted in China, Turkey and Iran (NIH-Clinical Trials Database, 2020; Identifier: NCT04350684) [119], but they are not yet concluded or do not have available results.

\subsubsection{Teicoplanin and Others}

Teicoplanin is a clinically approved glycopeptide antibiotic that inhibits cathepsin L activity and blocks MERS-CoV and SARS-CoV entry into cells [184] (Figure 2). More recently, this drug also showed antiviral activity against SARS-CoV-2 [185]. Similarly, another cathepsin $\mathrm{L}$ inhibitor, Z-FY(t-Bu)-DMK, and cysteine protease inhibitors E64d and K11777, have been shown to block the SARS-CoV infection [103,186]. Moreover, MG132, a proteasome and cysteine protease inhibitor, and MDL28170, an m-calpain inhibitor, effectively inhibited SARS-CoV replication [103]. These studies are based on the fact that SARS-CoV entry requires cathepsin L, cysteine protease and serine protease activity, and thus define viable pharmacological targets for COVID-19 management.

Taken together, antiviral agents proposed for SARS-CoV-2 infection treatment focus on preventing host cell invasion. For that reason, they act as a barrier against SARS-CoV-2 infection. Camostat mesylate, lopinavir and teicoplanin are potent protease inhibitors capable of hindering the S-protein cleavage required for viral infection. Umifenovir, on the other hand, does not display protease inhibitory activity, but hampers viral fusion with host cell membrane resulting in the same desired effect as the protease inhibitors. As proposed in many clinical trials, the combination of these drugs with lysosomotropic agents or PI3K/AKT/mTOR modulators may result in additive or synergistic effects upon viral replication, targeting multiple mechanisms involved in viral infectivity.

\subsection{PI3K/AKT/mTOR Modulators}

\subsubsection{Rapamycin}

Rapamycin is a PI3K/AKT/mTOR inhibitor and clinically proven macrolide that exhibits potent antitumor and immunosuppressive activity $[103,186]$ (Figure 2). While the antiviral activity of rapamycin is controversial [103], it was capable of reducing porcine epidemic diarrhea virus [187], transmissible gastroenteritis virus (TGEV) and CoVs infectivity [188].

Regarding specifically to CoVs, the PI3K inhibitor wortmannin inhibited MERS-CoV infection in Huh7 cells [61] and reduced vesicle formation in HEK cells that express infectious bronchitis virus (IBV) nsp6, thus indicating that nsp6-induced autophagy was dependent on PI3K [84]. Likewise, the inhibition of PI3K with VPS34-IN1 in Vero E6 cells and its bioavailable analogue VPS34-IN1 in ex vivo human lung tissues potently suppressed SARS-CoV-2 replication at a nanomolar level [189]. Moreover, the pharmacological 
inhibition of E3 ubiquitin ligase, a component of SKP2, decreased the ubiquitination and degradation of Beclin-1 and enhanced autophagic flux, consequently reducing MERS-CoV replication [60].

A very recent preprint reported that SARS-CoV-2 infection limits autophagy by interfering with various metabolic pathways and that compound-driven interventions aimed at inducing autophagy reduced the spread of SARS-CoV-2 in vitro. It has also shown that spermidine, MK-2206 (an AKT inhibitor), and niclosamide (a Beclin-1 stabilizing anthelminthic drug) inhibited the in vitro spread of SARS-CoV-2 by targeting these pathways [72].

In fact, upregulation of the PI3K/AKT/mTOR signaling pathway occurs during SARS-CoV-2 infection, as revealed by proteomics and transcriptomics data [190]. Authors showed the activation of AKT/mTOR signaling during initial phases of infection, and the inhibition of AKT by MK-2206 can suppress SARS-CoV-2 infection. Nonetheless, rapamycin has not shown an effective action to limit the infection. As mentioned above, Kindrachuk et al., (2015) showed that upregulation of the PI3K/AKT/mTOR pathway also occurs in MERS infection, which suggests its pivotal role in CoVs infection [61]. Thus, $\mathrm{PI} 3 \mathrm{~K} / \mathrm{AKT} / \mathrm{mTOR}$ inhibitors are attainable strategies to alleviate CoVs infections, such as MERS-CoV and SARS-CoV. Once the inhibition of this pathway with a library of kinase inhibitors suppresses the MERS infection, the use of PI3K/AKT/mTOR inhibitors represent a novel strategy to prevent SARS-CoV-2 infection.

In this way, not only the activation of autophagy with mTORC1 inhibitors could play a role in the SARS-CoV-2 infection, but compounds that can act in the PI3K/AKT/mTOR pathway, like the MK-2206, can promote the suppression of viral replication and spread, once this pathway regulates many cellular processes and not only autophagy. Until now, clinical trials employing rapamycin or other mTOR inhibitors are not concluded and are still recruiting patients (NIH-Clinical Trials Database; Identifier: NCT04341675, NCT04461340 and NCT04584710) [119], hindering any conclusion about clinical efficacy. Nevertheless, one study was withdrawn due to irregular admission to hospital and shifted approaches from repurposing old drugs (NCT04371640).

\subsubsection{Heparin}

Heparin exhibited several antiviral actions [191-194], probably due to its structural similarity to heparan sulfate [195], a glycosaminoglycan formed by proteoglycans present on the surface of cells that participates in viral entry into eukaryotic cells as an initial anchoring domain [191,196] (Figure 2). Thus, heparan sulfate appears to modulate the entry of SARS-CoV into cells. It has been shown that the SARS-CoV-2 Spike S1 receptor can bind to heparin, changing the receptor conformation [197]. Additionally, the treatment of Vero cells with heparin inhibited SARS-CoV-2 infection [197]. Additionally, using a heparin-like polysaccharide in cells infected with HPV, Gao et al., (2018) showed that sulfated chitasone attenuated the HPV infection in different cell lines and inhibited the $\mathrm{PI} 3 \mathrm{~K} / \mathrm{AKT} / \mathrm{mTOR}$ pathway, which is indicative of autophagy activation. These data suggest a relationship between heparin-related compounds with autophagy during viral infections. Concluded clinical trials employing heparin have not posted results so far (NIH-Clinical Trials Database; Identifier: NCT04359212 and NCT04518735) [119].

\subsubsection{Glucocorticoids}

Glucocorticoids (GCs) are steroid hormones with potent anti-inflammatory and immunosuppressive actions used in the treatment of chronic inflammatory, autoimmune and allergic diseases [198,199] (Figure 2).

During the SARS-CoV and MERS-CoV epidemics, GCs were widely used to decrease the exacerbated immune response caused by the uncontrolled release of proinflammatory cytokines observed during severe lung inflammation [200,201]. Consequently, GCs were proposed for the treatment of COVID-19 patients with mild to intermediate doses in an initial treatment of cytokine storm and in specific cases of COVID-19-induced pneumonia $[202,203]$. However, GCs may increase the risk of secondary infections and delay the 
clearance of the virus, as was observed with their use in infections caused by MERS-CoV and SARS-CoV [200,204].

In other viral infections, GCs exhibit an autophagy-dependent antiviral effect. For example, budesonide, a synthetic GC, was able to inhibit the replication of the HCoV-229E $\mathrm{CoV}$ and alters the luminal $\mathrm{pH}$ of acid endosomes [205]. Budesonide also reduced human rhinovirus (HRV) replication in HeLa cells by inducing autophagy, and this antiviral effect was attenuated in the presence of the autophagic blockers CQ and bafilomycin-A1 [206]. Similar effects were observed with dexamethasone in the same viral infection [207]. However, He et al. (2018) observed that dexamethasone stimulated HRV replication. The authors showed that this stimulation was autophagy-dependent since dexamethasone, in the presence of the autophagic inhibitor 3-methyl-adenine, reduced viral replication [208]. Together, these data show that the GC-mediated effect on viral replication depends on both the virus and the autophagy pathway.

In fact, GCs induce autophagy by negatively modulating mTORC1 [209-212] and the transcription of genes related to the mTORC1 pathways, such as MAPK/ERK and PI3K/AKT [213]. Additionally, GCs-induced autophagy involves the ubiquitin ligase TRIM32 (tripartite motif-containing 32) that is required for the induction of muscle autophagy under atrophic conditions [214].

Regarding SARS-CoV-2 replication, inhaled GCs reduce the expression of ACE2 and TMPRSS2 genes in patients with asthma [215] and attenuate ACE2 receptors in human and murine in vitro and in vivo models [216]. In agreement, steroidal sex hormones (estradiol, progesterone and testosterone) are implicated in the age-dependent and sexspecific severity of COVID-19 through mechanisms including modulation of the immune responses and ACE2 and/or TMPRSS2 levels [217-220]. For example, some evidence supports that estrogens and progesterone exert an immune-protective effect on women in COVID-19 by positively modulating immune $\mathrm{T}$ cells and a blockade of proinflammatory cytokine storm [221,222]. Estrogens can also downregulate ACE2 mRNA levels in bronchial epithelial cells in vitro [223]. In addition, 17 $\beta$-estradiol treatment reduced the levels of the TMPRSS2, which are involved with SARS-CoV-2 infectiveness capacity, and, hence, also reduced SARS-CoV-2 viral load [224]. Both high and low testosterone levels can favor severe COVID-19 [225,226], as high testosterone levels may upregulate TMPRSS2, facilitating the entry of SARS-CoV-2 into host cells. It was observed that androgens, besides their immunosuppressive effects via inhibition of the proinflammatory cytokine storm [227], can strongly upregulate the expression of TMPRSS2 in prostate cancer cells and human lung epithelial cells [228]. Thus, preclinical data demonstrates that blocking the activity of TMPRSS2 protease through camostat mesylate, nafamostat or bromhexine decreases the entry of SARS-CoV-2 into lung cells and may improve COVID-19 infection in men [229,230]. After the RECOVERY trial report, GCs such as corticosterone, have been recommended by WHO for severely ill COVID-19 patients, comprising one of the few available therapy for COVID-19 management [231]. While the results with GC and hormone-therapy appear to be promising, further studies on the action of these drugs in SARS-CoV-2 infection are necessary.

\subsubsection{Angiotensin-Converting Enzyme Inhibitors (IECAs) and Type 1 Angiotensin II Receptors Blockers (ARB)}

Several studies have shown that renin-angiotensin system (RAS) deregulation may be responsible for acute respiratory distress syndrome, which can be triggered by viruses (SARS-CoV, H5N1 and H7N9), bacteria and particles and molecules [232]. Therefore, excess angiotensin II may be primarily responsible for increased SARS-CoV pathogenesis [233]. Thus, these studies suggest that decreasing the angiotensin II levels or blocking the RAS pathway might attenuate acute lung injury severity. In the same context, a meta-analysis showed that the angiotensin receptor blocker and angiotensin-converting enzyme inhibitor (ACEI) reduce the risk of pneumonia and lower disease morbidity and mortality [234].

The type 1 angiotensin II receptor $\left(\mathrm{AT}_{1}\right)$ also controls several physiological processes, including autophagy. H. Xu et al., (2020) found that mechanical stress triggers cardiomy- 
ocyte autophagy through $\mathrm{AT}_{1}$ receptors, activating $\mathrm{p} 38 \mathrm{MAP}$ kinase-independent of angiotensin II [235]. The type 2 angiotensin II receptor $\left(\mathrm{AT}_{2}\right)$ blocker PD1223319 failed to abolish autophagy, thus confirming that angiotensin II induces autophagy through $\mathrm{AT}_{1}$ receptors [236]. Furthermore, it was demonstrated that angiotensin II increases the number of autophagosomes in cells with high level of $\mathrm{AT}_{1}$ receptors and these effects were antagonized when cells coexpressed the $\mathrm{AT}_{2}$ receptor [237].

Additionally, the treatment of ACE inhibitors or ARB was effective on COVID-19 patients with lower complications. For instance, Zhang et al., (2019) found that ACE2 activation or inhibition in lung tissue affected the severity of acute lung injury by modulating levels of proinflammatory factors and autophagy induction through the AMPK/mTOR pathway [238]. In favor of these findings, hospitalized patients with COVID-19 using ACEI/ARB had a lower risk of disease-induced mortality when compared to non-users of these drugs [239]. Additionally, in a retrospective multicenter study conducted in China, with 1128 hypertensive patients diagnosed with COVID-19 (188 received ACE inhibitors or $\mathrm{ARB}$ and 940 without receiving ACEI/ARB), the mortality rate was higher in the population that did not receive ARB/ACEI drugs (9.8\% vs. 3.7\%) [239]. Nonetheless, results from completed clinical trials employing ACEI/ARB are not yet available (NIH-Clinical Trials Database; Identifier: NCT04318301, NCT04357535 and NCT04318418) [119].

\subsubsection{Cannabidiol}

Cannabidiol, a phytocannabinoid from Cannabis sativa, is effective at treating arthritis, ear inflammation, inflammatory bowel disease, neuroinflammation and pulmonary inflammatory disease [240-244] (Figure 2).

Cannabidiol produces no psychotropic effects and has a safe and tolerable dose range, making it an attractive drug [245]. Aside from its anti-inflammatory and immunomodulatory effects, there is little if any evidence that cannabidiol could be effective against viral infections [246]. For example, cannabidiol decreased neuroinflammation by negatively regulating chemokine (C-C motif) ligand type 2 and 5 (CCL2 and CCL5) and the proinflammatory cytokine interleukin- $\beta$ (IL-1 $\beta$ ) induced by Theiler's murine encephalomyelitis virus (TMEV) in mice [247]. These findings are supported by other research demonstrating the attenuated production and release of IL- $1 \beta$, IL- 6 and IL- $\beta$ in BV-2 in lipopolysaccharide activated microglia treated with cannabidiol [248]. Cannabidiol treatment also decreased the levels of IL-4, IL-5, IL-13, IL-6 and tumor necrosis factor $\alpha$ (TNF- $\alpha)$ in an experimental model of asthma in rats, consequently reducing airway inflammation and fibrosis [249]. Along with these lines, it is known that SARS-CoV-2 infection leads to a proinflammatory cytokine storm [250]; thus, cannabidiol might decrease the levels of these cytokines and benefit patients infected with SARS-CoV-2 [251].

A group of researchers in Canada recently showed that extracts from C. sativa containing high levels of cannabidiol downregulate the expression of the ACE2 gene and TMPRSS2, which, as discussed previously, are the primary receptors for SARS-CoV-2 entry into host cells, in different models of human epithelia [252]. Additionally, cannabidiol can act as an antioxidant at several receptor sites, including the peroxisome proliferator-activated $\gamma(\operatorname{PPAR} \gamma)$ and adenosine 2 receptors [253]. Concerning PPAR $\gamma$, it is highly expressed in the alveolar macrophage in acute pneumonia and is responsible for controlling the pulmonary inflammatory processes that promote tissue recovery after viral respiratory infections [254]. In this sense, cannabidiol action at PPAR $\gamma$ receptor sites may produce a considerable improvement in lung function by preventing the cytokine storm of resident macrophages [243,254,255].

Cannabidiol induces autophagy in different cell types, which can play either a protective or harmful role, depending on the stimulus and exposure time [256]. For example, one study demonstrated that cannabidiol induced autophagy by increasing the formation of autophagosomes and inhibiting autophagosome degradation in an intestinal epithelium model [257]. The activation of autophagy also involves the ERK $1 / 2$ and PI3K/AKT signaling pathways, which are modulated by cannabidiol [258]. A previous study reported 
autophagy activation via the ERK/MAPK cascade, leading to the attenuation of AKT phosphorylation induced by growth factors [259]. Furthermore, Hiebel et al., (2014) showed that autophagy could be modulated by the cannabinoid receptor type 1 (CB1) independently of the mTOR and Beclin-1 complex [260].

Presently, clinical trials employing cannabidiol are still recruiting and not concluded (NCT03944447). Thus, although further investigations are necessary to evaluate the effects of cannabidiol on viral infections, inflammation, immune system control and autophagy, there is a plethora of data supporting the hypothesis that it may be a safe and useful adjuvant therapy for SARS-CoV-2.

The coronavirus family is known to avoid autophagy and escape endosomal degradation [261,262], but whether these viruses induce or arrest the autophagy machinery is unclear. Nevertheless, autophagy favors immunity in respiratory diseases $[263,264]$ as it facilitates the selective disintegration of immunogenic components associated with viral particles, benefiting pattern recognition in innate immune response and antigen presentation in adaptive immunity [262]. Coronavirus also upregulates PI3K/AKT/mTOR signaling, and kinase inhibitors such as wortmannin (PI3K inhibitor), MK-2206 (AKT inhibitor) and rapamycin (mTOR inhibitor) restrains CoVs infection in vitro [60,61,190]. The use of $\mathrm{PI} 3 \mathrm{~K} / \mathrm{AKT} / \mathrm{mTOR}$ inhibitors could hinder autophagy appropriation by CoVs, but also favor immunity and antigen presentation, and benefit the secretion of anti-inflammatory cytokines and tissue repair [95,265-267].

In order to offer an overview on the proposed mechanisms, we summarized several clinically approved and tolerated autophagy-modulating drugs described here with their respective ongoing clinical trials for the management of COVID-19 (Table 2), and their conventional therapeutic use and toxicological properties (Table 3). The results of these trials will be essential for a better evaluation of the clinical potential and evaluation of the therapeutic strategy, dose and posology, as a safe estimation of risk/benefit is very challenging without population parameters. 
Table 2. Potential autophagy-related drugs for SARS-CoV-2 infection.

\begin{tabular}{|c|c|c|c|c|c|}
\hline Drug & Mechanisms & $\begin{array}{l}\text { Activity } \\
\text { (In Vitro) }\end{array}$ & Cell Model & Ref. & $\begin{array}{c}\text { Current Clinical Trials } \\
\text { Number/Phase }\end{array}$ \\
\hline & 1. Lysosomotropic agents & & & & \\
\hline \multirow{4}{*}{$\begin{array}{l}\text { Chloroquine/ } \\
\text { hydroxychloroquine }\end{array}$} & \multirow{4}{*}{$\begin{array}{l}\text {-Prevents endolysosomal } \\
\quad \text { acidification; } \\
\text {-Blockade of cathepsin activity; } \\
\text {-Intracellular retention of ACE2. }\end{array}$} & SARS-CoV-2 & Vero E6 & [268] & \multirow{4}{*}{$\begin{array}{l}\text { NCT04341727/Phase } 3 \\
\text { NCT04328272/Phase } 3\end{array}$} \\
\hline & & SARS-CoV-2 & Vero E6 & [110] & \\
\hline & & SARS-CoV & HEK293E; Vero E6 & [117] & \\
\hline & & SARS-CoV & Vero E6 & [106] & \\
\hline \multirow{5}{*}{ Azithromycin } & \multirow{5}{*}{$\begin{array}{l}\text {-Acidotropic lipophilic weak base with similar effects to CQ in vitro; } \\
\text {-Possible synergy with HCQ for competitive inhibition of SARS-CoV-2 } \\
\text { attachment to the host-cell membrane; } \\
\text {-Blockade of viral internalization in the early phase of viral infections; } \\
\text {-Increases the production of interferon-stimulated genes in } \\
\text { rhinoviral infections. }\end{array}$} & $\begin{array}{l}\text { SARS-CoV-2 } \\
\text { (presumed) }\end{array}$ & IB3-1 & [126] & \multirow{5}{*}{$\begin{array}{l}\text { NCT04321278/Phase } 3 \\
\text { NCT04381962/Phase } 3\end{array}$} \\
\hline & & H1N1 & A549 & {$[125]$} & \\
\hline & & ZIKV & Vero, U87 & {$[124]$} & \\
\hline & & EBOV & Vero E6 & [123] & \\
\hline & & HRV & HBECs & [122] & \\
\hline $\begin{array}{l}\text { Artemisinin and its } \\
\text { derivative } \\
\text { compounds }\end{array}$ & $\begin{array}{l}\text {-Inhibition of NF-kB; } \\
\text {-Chloroquine-like endocytosis inhibition mechanism. }\end{array}$ & SARS-CoV-2 & Vero E6 & {$[144,269]$} & $\begin{array}{l}\text { NCT04387240/Phase } 2 \\
\text { NCT04382040/Phase } 2\end{array}$ \\
\hline \multirow{3}{*}{ Tetrandrine and ned-19 } & \multirow{3}{*}{$\begin{array}{l}\text {-Pharmacological inhibition of TPCs; } \\
\text {-Inhibition of viral translocation and motility in the endosomal system. }\end{array}$} & EBOV & $\mathrm{HeLa}$ & [158] & \multirow{3}{*}{ NCT04308317/Phase 4} \\
\hline & & MERS-CoV & Huh7 & {$[160]$} & \\
\hline & & HIV-1 & U87MG & [270] & \\
\hline \multirow{2}{*}{ Imatinib } & \multirow{2}{*}{$\begin{array}{l}\text {-Inhibitor of ABL-2; } \\
\text {-Inhibition of the virion fusion at the endosomal membrane. }\end{array}$} & $\begin{array}{l}\text { SARS-CoV, } \\
\text { IBV }\end{array}$ & Vero E6 & [162] & \multirow{2}{*}{$\begin{array}{l}\text { NCT04422678/Phase } 3 \\
\text { NCT04346147/Phase } 4\end{array}$} \\
\hline & & $\begin{array}{l}\text { SARS-CoV, } \\
\text { MERS-CoV }\end{array}$ & $\begin{array}{l}\text { Vero E6, MRC5, Calu-3, } \\
\text { Huh7, BSC1 }\end{array}$ & [164] & \\
\hline & 2. Protease inhibitors/Antiviral agents & & & & \\
\hline \multirow{2}{*}{$\begin{array}{l}\text { Camostat } \\
\text { mesylate }\end{array}$} & \multirow{2}{*}{$\begin{array}{l}\text {-Prevents the viral entrance on host cell; } \\
\text {-Inhibition of TMPRSS2, a serine protease that cleaves the spike S } \\
\text { protein after viral bound to ACE2 receptor. }\end{array}$} & SARS-CoV-2 & Calu-3 and Vero & [101] & \multirow{2}{*}{$\begin{array}{l}\text { NCT04338906/Phase } 4 \\
\text { NCT04353284/Phase } 2\end{array}$} \\
\hline & & SARS-CoV & Caco2 & [175] & \\
\hline
\end{tabular}


Table 2. Cont.

\begin{tabular}{|c|c|c|c|c|c|}
\hline Drug & Mechanisms & $\begin{array}{c}\text { Activity } \\
\text { (In Vitro) }\end{array}$ & Cell Model & Ref. & $\begin{array}{l}\text { Current Clinical Trials } \\
\text { Number/Phase }\end{array}$ \\
\hline \multirow{5}{*}{$\begin{array}{l}\text { Lopinavir/ } \\
\text { ritonavir }\end{array}$} & \multirow{5}{*}{$\begin{array}{c}\text {-Protease inhibitor that prevent viral replication and spread; } \\
\text {-Inhibition of protease type 3C; } \\
\text { Ritonavir inhibits CYP450. }\end{array}$} & SARS-CoV-2 & Vero E6 & [271] & \multirow{5}{*}{$\begin{array}{l}\text { NCT04307693/Phase } 2 \\
\text { NCT04372628/Phase } 2\end{array}$} \\
\hline & & SARS-CoV-2 & Vero E6 & [272] & \\
\hline & & SARS-CoV-2 & Vero E6 & [273] & \\
\hline & & SARS-CoV & FRhK-4 & [274] & \\
\hline & & MERS-CoV & Vero, Huh7 & [275] & \\
\hline Umifenovir & $\begin{array}{c}\text {-Prevents the viral invasion of host cell binding to membrane lipids; } \\
\text {-Binds to membrane proteins like clathrin, preventing viral } \\
\text { endocytosis through clathrin receptors. }\end{array}$ & $\begin{array}{l}\text { LASV, } \\
\text { EBOV }\end{array}$ & HEK293/17 and BSC-1 & [182] & $\begin{array}{l}\text { NCT04476719/Phase } 4 \\
\text { NCT04260594/Phase } 4\end{array}$ \\
\hline \multirow{2}{*}{$\begin{array}{l}\text { Teicoplanin } \\
\text { and others }\end{array}$} & \multirow{2}{*}{-Reduces viral invasion by inhibition of cathepsin L activity. } & $\begin{array}{l}\text { EBOV MERS-CoV } \\
\text { SARS-CoV }\end{array}$ & HEK293, A549 and HeLa & [184] & \multirow{2}{*}{$\begin{array}{l}\text { IRCT20161204031229N3 } \\
\text { Phase } 3\end{array}$} \\
\hline & & SARS-CoV-2 & HEK293 and Huh7 & [185] & \\
\hline & 3. PI3K/AKT/mTOR modulators & & & & \\
\hline \multirow{2}{*}{ Rapamycin } & \multirow{2}{*}{-Inhibition of mTOR pathway; } & PEDV & IPEC-J2 & [187] & \multirow{2}{*}{$\begin{array}{l}\text { NCT04482712/ } \\
\text { Phase } 1 \text { and } 2\end{array}$} \\
\hline & & MERS-CoV & Huh7 & {$[61]$} & \\
\hline \multirow{2}{*}{ Wortmannin } & \multirow{2}{*}{-Phosphatidylinositol 3-kinase (PI3K) pathway inhibition; } & TGEV & ST, PK15 & [188] & \multirow{2}{*}{$\mathrm{N} / \mathrm{A}$} \\
\hline & & MERS-CoV & Huh7 & [61] & \\
\hline \multirow{4}{*}{ Heparin } & \multirow{4}{*}{$\begin{array}{l}\text {-Inhibition of viral binding with glycosaminoglycans present on the } \\
\text { cell surface; }\end{array}$} & SARS-CoV-2 & Vero E6 & [197] & \multirow{4}{*}{ NCT04530578/Phase 4} \\
\hline & & SARS-CoV & Vero E6 & [194] & \\
\hline & & SARS-CoV & $\begin{array}{l}\text { HEK293E/ACE2-Myc, } \\
\text { Vero E6, Caco-2 }\end{array}$ & [196] & \\
\hline & & $\mathrm{HCV}$ & $\mathrm{IHH}$ & [192] & \\
\hline \multirow{2}{*}{ Glucocorticoids } & \multirow{2}{*}{$\begin{array}{c}\text {-Glucocorticoid receptor-dependent autophagy activation; } \\
\text {-Inhibition of IL-1 } \beta \text {, IL-6, IL-8 NF-kB, IFN- } \beta \text {, IFN- } \lambda 1 \text { and IFN- } \gamma \\
\text { mediated inflammation; }\end{array}$} & HCoV-229E & $\begin{array}{l}\text { HNE, } \\
\text { HTE }\end{array}$ & [205] & \multirow{2}{*}{ NCT04438980/Phase 3} \\
\hline & & HRV & $\begin{array}{c}\text { HeLa, } \\
\text { Vero E6 }\end{array}$ & [206] & \\
\hline
\end{tabular}


Table 2. Cont.

\begin{tabular}{|c|c|c|c|c|c|}
\hline Drug & Mechanisms & $\begin{array}{c}\text { Activity } \\
\text { (In Vitro) }\end{array}$ & Cell Model & Ref. & $\begin{array}{c}\text { Current Clinical Trials } \\
\text { Number/Phase }\end{array}$ \\
\hline Losartan & -Inhibition of the $\mathrm{AT}_{1}$ receptor; & SARS-CoV & $\begin{array}{c}\text { Mice } \\
\text { (in vivo) }\end{array}$ & [276] & NCT04335123/Phase 1 \\
\hline \multirow{2}{*}{ Cannabidiol } & \multirow{2}{*}{$\begin{array}{l}\text {-Inhibition of the transmigration of blood leukocytes; } \\
\text {-Downregulation of the vascular cell adhesion molecule-1 (VCAM-1), } \\
\text { chemokines (CCL2 and CCL5) and the proinflammatory cytokine } \\
\text { IL-1 } 3 \text { expression; } \\
\text {-Attenuation of microglial activation. }\end{array}$} & HIV & $\begin{array}{l}\text { Human } \\
\text { (in vivo) }\end{array}$ & {$[277,278]$} & \multirow{2}{*}{$\begin{array}{l}\text { NCT04467918/ } \\
\text { Phase } 2 \text { and } 3\end{array}$} \\
\hline & & TMEV & $\begin{array}{c}\text { Mice } \\
\text { (in vivo) }\end{array}$ & [247] & \\
\hline
\end{tabular}

Table 3. Therapeutic and toxicological properties for potential autophagy-related drugs against SARSCoV-2 infection according to the PubChem database [279].

\begin{tabular}{|c|c|c|c|}
\hline Drug & $\begin{array}{c}\text { Therapeutic } \\
\text { Properties }\end{array}$ & $\begin{array}{c}\text { Toxicological } \\
\text { Properties }\end{array}$ & Compound ID (CID) \\
\hline Chloroquine/hydroxycloroquine & $\begin{array}{l}\text { - } \quad \text { Malaria and amebiasis treatment and prevention; } \\
\text { Rheumatic diseases (i.e., systemic lupus erythematosus } \\
\text { and rheumatoid arthritis) treatment. }\end{array}$ & $\begin{array}{l}\text { - Corneal deposits, posterior subcapsular lens opac- } \\
\text { ity, ciliary body dysfunction, retinopathy and car- } \\
\text { diac rate changes. }\end{array}$ & $\begin{array}{l}2719 \\
3652\end{array}$ \\
\hline Azithromicin & $\begin{array}{l}\text { Mild-to-moderate Gram positive (i.e., staphylococci) and } \\
\text { Gram negative (i.e., Mycoplasma pneumonia) bacterial in- } \\
\text { fections treatment; } \\
\text { Protozoan infections (i.e., Toxoplasma gondii and T. cryp- } \\
\text { tosporidia ) treatment. }\end{array}$ & $\begin{array}{l}\text { - Hepatotoxicity, nephrotoxicity and severe cuta- } \\
\text { neous reactions (i.e., erythema multiforme and } \\
\text { toxic epidermal necrosis). }\end{array}$ & 447043 \\
\hline Artemisinin & - $\quad$ Leishmaniasis and Malaria treatment. & $\begin{array}{l}\text { - Sedative in rodent models but no significant toxic- } \\
\text { ity has been reported in humans; } \\
\text { - Cardiotoxicity and QT interval prolongation }\end{array}$ & 68827 \\
\hline Tetrandrine & $\begin{array}{l}\text { - Adjunctive therapy to chemotherapy in various cancer } \\
\text { types with multiple drug resistance; } \\
\text { - Antiviral activity against Ebola virus; } \\
\text { - Anti-inflammatory and antifibrogenic actions in lung sili- } \\
\text { cosis, liver cirrhosis, and rheumatoid arthritis. }\end{array}$ & $\begin{array}{l}\text { - Local pain, phlebitis and tissue irritation; } \\
\text { Mild and transient hearing loss, peripheral neu- } \\
\text { ropathy, cerebellar toxicity and cardiotoxicity. }\end{array}$ & 73078 \\
\hline
\end{tabular}


Table 3. Cont.

\begin{tabular}{|c|c|c|c|}
\hline Drug & $\begin{array}{l}\text { Therapeutic } \\
\text { Properties }\end{array}$ & $\begin{array}{c}\text { Toxicological } \\
\text { Properties }\end{array}$ & Compound ID (CID) \\
\hline Imatinib & $\begin{array}{l}\text { - Treatment of chronic myeloid leukemia, lymphoblastic } \\
\text { leukemia, myelodysplastic/myeloproliferative diseases, } \\
\text { aggressive systemic mastocytosis, hypereosinophilic syn- } \\
\text { drome and/or chronic eosinophilic leukemia, dermatofi- } \\
\text { brosarcoma protuberans and malignant gastrointestinal } \\
\text { stromal tumors. }\end{array}$ & $\begin{array}{l}\text { - Edema, nausea, vomiting, muscle cramps, muscu- } \\
\text { loskeletal pain, diarrhea, rash, fatigue and abdom- } \\
\text { inal pain. }\end{array}$ & 5291 \\
\hline Camostat mesylate & - Chronic pancreatitis. & - $\quad \mathrm{N} / \mathrm{A}$ & 5284360 \\
\hline Lopinavir/ritonavir & $\begin{array}{l}\text { - Antiretroviral activity against Human Immunodeficiency } \\
\text { Virus-1 (HIV-1). }\end{array}$ & $\begin{array}{l}\text { - Atrioventricular block, cardiomyopathy, lactic aci- } \\
\text { dosis, and acute renal failure. }\end{array}$ & 11979606 \\
\hline Umifenovir & $\begin{array}{l}\text { Broad-spectrum antiviral against influenza and other res- } \\
\text { piratory viral infections, Flavivirus, Zika virus, foot-and- } \\
\text { mouth disease, Lassa virus, Ebola virus and herpes simplex. }\end{array}$ & $\begin{array}{l}\text { - Chronic administration of doses } 10-50 \text { times } \\
\text { higher than the therapeutic human dose resulted } \\
\text { in no pathological changes to animal subjects. }\end{array}$ & 131411 \\
\hline Teicoplanin & $\begin{array}{l}\text { - Antibiotic against pseudomembranous colitis and Clostrid- } \\
\text { ium difficile. }\end{array}$ & - Change in auditory acuity and ototoxicity. & 133065662 \\
\hline Rapamycin & $\begin{array}{l}\text { - Potent immunosuppressant with both antifungal and an- } \\
\text { tineoplastic properties. }\end{array}$ & $\begin{array}{l}\text { - Peripheral edema, hypercholesterolemia, abdom- } \\
\text { inal pain, headache, nausea, diarrhea, chest pain, } \\
\text { stomatitis, nasopharyngitis, acne, upper respira- } \\
\text { tory tract infection, dizziness and myalgia. }\end{array}$ & 5284616 \\
\hline Heparin & $\begin{array}{ll}\text { - } & \text { Anticoagulant; } \\
\text { - } & \text { Antitumoral agent with angiogenesis inhibiting properties. }\end{array}$ & $\begin{array}{l}\text { - Heparin-induced thrombocytopenia, which may } \\
\text { progress to arterial thrombosis, gangrene, stroke, } \\
\text { myocardial infarction; } \\
\text { - } \quad \text { Spontaneous fractures and osteoporosis. }\end{array}$ & 772 \\
\hline
\end{tabular}


Table 3. Cont

\section{Drug}

Dexamethasone (glucocorticoid)
- Anti-inflammatory and immunosuppressive agent for a number of endocrines, rheumatic, collagen, dermatologic, allergic, ophthalmic, gastrointestinal, respiratory, hematologic, neoplastic, edematous and other conditions.

\section{Toxicological \\ Properties}

- Chronic high doses of glucocorticoids can lead to the development of cataract, glaucoma, hypertension, water retention, hyperlipidemia, peptic ul-

cer, pancreatitis, myopathy, osteoporosis, mood changes, psychosis, dermal atrophy, allergy, acne, hypertrichosis, immune suppression, decreased resistance to infection, moon face, hyperglycemia hypocalcemia, hypophosphatemia, metabolic acidosis, growth suppression and secondary adrenal insufficiency.
Compound ID (CID)

- Hypotension, tachycardia, or bradycardia due to vagal stimulation.

- Antihypertensive able to reduce the risk of stroke in patients.

- $\quad$ Sedation, somnolence and fatigue;

- Analgesic, anticonvulsant, muscle relaxant, anxiolytic and antipsychotic agent;

- Treatment of rare forms of refractory epilepsy syndromes.
- Drug-drug interactions and hepatic abnormalities.

644019 


\section{Conclusions}

Due to its rapid spread, high lethality and impact on health systems, the COVID-19 pandemic caused by SARS-CoV-2 represents one of the most significant challenges ever faced by the modern world. The lack of knowledge about the virus and access to a viable vaccine has forced researchers and medical professionals to identify alternative compounds and drugs that can be effective in containing the pandemic. In this review, we discussed the potential of autophagy inhibitors in the treatment of COVID-19 infection, and offered a justification for the mechanism related to autophagy for the potential antiviral activity of these drugs.

In this regard, the initial debate orbited around lysosomotropic agents, such as $\mathrm{CQ} / \mathrm{HCQ}$, as potential off-label drugs for the treatment of COVID-19. Unfortunately, clinical trials have failed to demonstrate any therapeutic benefit for CQ/HCQ, since the lysosomotropic agents have shown limited efficacy and safety due to the nonspecific action on acidophilic organelles. In contrast, agents that mediate their effects through specific mechanisms, such as protease inhibitors and antiviral drugs, have superior clinical potential due to their reduced side effects. Several of these drugs are still under clinical investigation and are expected to be well tolerated and to reduce the severe clinical outcomes of COVID-19. At the same time, PI3K/AKT/mTOR inhibitors, such as rapamycin, are potent anti-inflammatory and immunosuppressive agents that can offer therapeutic benefits against COVID-19. For example, GCs induce autophagy by negatively modulating mTORC1 and are one of the few therapies available for the management of COVID-19 recommended by WHO. Nonetheless, the use of these drugs appears to be limited to specific clinical circumstances since GCs are indicated for severely ill patients who suffer from cytokine storm and aggravated inflammation. Finally, combined therapy with more than one of the proposed drugs should not be disregarded, as complementary antiviral mechanisms can offer additive therapeutic effects with few side effects to patients with COVID-19.

However, in order to establish the appropriate therapeutic strategy and define the risk/benefit of the proposed drugs, the conclusion of the clinical trials is essential. We hope that the drugs listed here can demonstrate a beneficial effect against COVID-19 in clinical trials and then integrate future international protocols for the treatment of COVID-19.

Author Contributions: G.J.d.S.P., A.H.F.F.L., M.P., G.M.F., P.R., S.S.S., C.B. Study supervision, conception and design of the manuscript, tables and figures. A.H.F.F.L., A.G.E., M.P., G.M.F., G.J.d.S.P., P.R., S.S.S., C.B. Review and writing of coronaviruses: mechanisms of infections and replication, and autophagy: conceptions and cell signaling. G.J.d.S.P., A.H.F.F.L., L.d.S.Z., L.d.O.M., L.P.S. Lysosomotropic agent's revision. S.S.S., C.B., I.B.d.M.M., T.A.d.M.V. PI3K/AKT/mTOR regulators revision. P.R., C.A.S.P., Í.V.F.L., I.B.d.M.M. Protease inhibitors revision. All authors have read and agreed to the published version of the manuscript.

Funding: This study was supported by Fundação de Amparo à Pesquisa do Estado de São PauloFAPESP: 2017/10863-7; 2019/14722-4 (GJSP); 2019/02821-8 (SSS); Conselho Nacional de Desenvolvimento Científico e Tecnológico: Universal 421603/2018-6 (GJSP); PVE 401236/2014-5 (SSS); PVE 401141/2014-4 (CB).

Institutional Review Board Statement: Not applicable.

Informed Consent Statement: Not applicable.

Conflicts of Interest: The authors declare no conflict of interest.

\section{Abbreviations}

2019-nCoV 2019 novel coronavirus 
Ambra1

AMPK

ARB

AT1

AT2

Atg/ATG

BCL-2

BCR-ABL

BECN1

CB1

Beclin-1/Vps34

CCL

COVID-19

CoVs

CQ

DMVs

EBOV

EIF4B

EIF4F

EIF4G1

ER

ERK

FDA

GABARAP

GDI2

GCs

GFP

H1N1

HBV

HCMV

HCQ

$\mathrm{HCV}$

HIV

HNE

HPV

HRV

HSV-1/HSV-2

IBV

IECAs

IL-1 $\beta$

LASV

LC3

LIR

MAP1LC3

MAPK

MERS-CoV

MHRA

mTORC1

NAADP

NF-KB

NHS

$\mathrm{NIH}$

Nsp

Orf activating molecule in Beclin 1-regulated autophagy

protein kinase activated by AMP

angiotensin receptor blocker

type 1 angiotensin II receptor

type 2 angiotensin II receptor

autophagy-related protein/gene

B-cell lymphoma 2

breakpoint cluster region gene-Abelson proto-oncogene

beclin-1 gene

cannabinoid receptor type 1

Beclin-1/vacuolar protein sorting 34

chemokine (C-C motif) ligand

Coronavirus Disease 2019

coronavirus

chloroquine

double-membrane vesicles

Ebola virus

eukaryotic translation initiation factor $4 \mathrm{~B}$

eukaryotic translation initiation factor $4 \mathrm{~F}$

Eukaryotic Translation Initiation Factor 4 Gamma 1

endoplasmic reticulum

extracellular signal-regulated kinase

Food and Drug Administration

gamma-aminobutyric acid receptor-associated protein

Guanosine nucleotide diphosphate dissociation inhibitor 2

glucocorticoids

green fluorescent protein

influenza A

hepatitis B virus

human cytomegalovirus

hydroxychloroquine

hepatitis $C$ virus

human immunodeficiency virus

human nasal epithelial cells

human papilloma virus

human rhinovirus

human herpes simplex virus 1 and 2

infectious Bronchitis Virus

angiotensin-converting enzyme inhibitors

interleukin-1 $\beta$

Lassa virus

microtubule-associated protein 1A/1B-light chain 3

LC3-interacting region

Microtubule-Associated Protein 1A/1B-Light Chain 3

mitogen-activated protein kinase

Middle-East respiratory syndrome coronavirus

Medicines and Healthcare products Regulatory Agency

mammalian target of rapamycin complex 1

Nicotinic Acid Adenine Dinucleotide Phosphate

nuclear factor kappa B

National Health Service

National Institute of Health

nonstructural protein

open reading frame 


\begin{tabular}{|c|c|}
\hline PEDV & porcine epidemic diarrhea virus \\
\hline PI3K & phosphoinositide 3-kinase \\
\hline PI3P & phosphatidylinositol 3-phosphate \\
\hline PLP2-TM & papain-like protease PLP2 \\
\hline $\operatorname{PPAR} \gamma$ & peroxisome proliferator-activated receptor $\gamma$ \\
\hline RAS & renin-angiotensin system \\
\hline RAB1A & Ras-related protein Rab-1A \\
\hline RAB6A & Ras-related protein Rab-6A \\
\hline RAB6D & Ras-related protein Rab-6D \\
\hline RAB7A & Ras-related protein Rab-7A \\
\hline RECOVERY & Randomised Evaluation of COVID-19 Therapy \\
\hline RNA & ribonucleic acid \\
\hline S & Spike \\
\hline SARS-CoV & severe acute respiratory syndrome coronavirus \\
\hline SARS-CoV-2 & severe acute respiratory syndrome coronavirus 2 \\
\hline SCFD1 & sec1 family domain containing 1 \\
\hline SQSTM1 & sequestosome-1 \\
\hline SKP2 & S-phase kinase-associated protein 2 \\
\hline SNAP29 & synaptosome associated protein 29 \\
\hline SNARE & N-ethylmaleimide-sensitive factor attachment protein receptor \\
\hline STAT3 & signal transducer and activator of transcription 3 \\
\hline Stx17 & Syntaxin 17 \\
\hline TFEB & Transcription Factor EB \\
\hline TGEV & transmissible gastroenteritis virus \\
\hline TMEV & Theiler's murine encephalomyelitis virus \\
\hline TMPRSS2 & transmembrane serine protease 2 \\
\hline $\mathrm{TNF}-\alpha$ & tumor necrosis factor $\alpha$ \\
\hline TPCs & Two-Pore Channels \\
\hline TRIM32 & tripartite motif-containing 32 \\
\hline TRPML1 & transient receptor potential mucolipin 1 \\
\hline ULK1 & Unc-51-like autophagy activating kinase 1 \\
\hline UNC-5 & Netrin receptor UNC-5 (Uncoordinated protein 5) \\
\hline USO1 & General vesicular transport factor p115 \\
\hline USA & United States of America \\
\hline VAMP8 & lysosomal vesicle-associated membrane protein 8 \\
\hline VPS 34 & vacuolar protein sorting 34 \\
\hline VPS 34-IN1 & vacuolar protein sorting 34 inhibitor 1 \\
\hline WHO & World Health Organization \\
\hline WIPI & WD repeat domain phosphoinositide-interacting protein \\
\hline$\beta-\mathrm{CoVs}$ & Betacoronavirus genus \\
\hline
\end{tabular}

\section{References}

1. Huang, C.; Wang, Y.; Li, X.; Ren, L.; Zhao, J.; Hu, Y.; Zhang, L.; Fan, G.; Xu, J.; Gu, X.; et al. Clinical features of patients infected with 2019 novel coronavirus in Wuhan, China. Lancet 2020, 395, 497-506. [CrossRef]

2. Zhou, P.; Yang, X.L.; Wang, X.G.; Hu, B.; Zhang, L.; Zhang, W.; Si, H.R.; Zhu, Y.; Li, B.; Huang, C.L.; et al. A pneumonia outbreak associated with a new coronavirus of probable bat origin. Nature 2020, 579, 270-273. [CrossRef] [PubMed]

3. Liu, Y.C.; Kuo, R.L.; Shih, S.R. COVID-19: The first documented coronavirus pandemic in history. Biomed. J. 2020, 43, 328-333 [CrossRef] [PubMed]

4. Gorbalenya, A.E.; Baker, S.C.; Baric, R.S.; de Groot, R.J.; Drosten, C.; Gulyaeva, A.A.; Haagmans, B.L.; Lauber, C.; Leontovich A.M.; Neuman, B.W.; et al. The species Severe acute respiratory syndrome-related coronavirus: Classifying 2019-nCoV and naming it SARS-CoV-2. Nat. Microbiol. 2020, 5, 536-544.

5. Neilson, S. Aylin Woodward Coronavirus: A 1-Year Timeline of the Pandemic Since China's 1st Case-Business Insider. Available online: https:/ / www.businessinsider.com/coronavirus-pandemic-timeline-history-major-events-2020-3 (accessed on 24 December 2020). 
6. Sarkar, R.; Mitra, S.; Chandra, P.; Saha, P.; Banerjee, A.; Dutta, S.; Chawla-Sarkar, M. Comprehensive analysis of genomic diversity of SARS-CoV-2 in different geographic regions of India: An endeavour to classify Indian SARS-CoV-2 strains on the basis of co-existing mutations. Arch. Virol. 2021. [CrossRef]

7. Gómez-Carballa, A.; Bello, X.; Pardo-Seco, J.; Martinón-Torres, F.; Salas, A. Mapping genome variation of SARS-CoV-2 worldwide highlights the impact of COVID-19 super-spreaders. Genome Res. 2020, 30, 1434-1448. [CrossRef] [PubMed]

8. Zhu, N.; Zhang, D.; Wang, W.; Li, X.; Yang, B.; Song, J.; Zhao, X.; Huang, B.; Shi, W.; Lu, R.; et al. A novel coronavirus from patients with pneumonia in China, 2019. N. Engl. J. Med. 2020, 382, 727-733. [CrossRef]

9. Drosten, C.; Günther, S.; Preiser, W.; van der Werf, S.; Brodt, H.-R.; Becker, S.; Rabenau, H.; Panning, M.; Kolesnikova, L.; Fouchier, R.A.M.; et al. Identification of a Novel Coronavirus in Patients with Severe Acute Respiratory Syndrome. N. Engl. J. Med. 2003, 348, 1967-1976. [CrossRef] [PubMed]

10. Ksiazek, T.G.; Erdman, D.; Goldsmith, C.S.; Zaki, S.R.; Peret, T.; Emery, S.; Tong, S.; Urbani, C.; Comer, J.A.; Lim, W.; et al. A Novel Coronavirus Associated with Severe Acute Respiratory Syndrome. N. Engl. J. Med. 2003, 348, 1953-1966. [CrossRef]

11. Zaki, A.M.; van Boheemen, S.; Bestebroer, T.M.; Osterhaus, A.D.M.E.; Fouchier, R.A.M. Isolation of a Novel Coronavirus from a Man with Pneumonia in Saudi Arabia. N. Engl. J. Med. 2012, 367, 1814-1820. [CrossRef]

12. Wang, D.; Hu, B.; Hu, C.; Zhu, F.; Liu, X.; Zhang, J.; Wang, B.; Xiang, H.; Cheng, Z.; Xiong, Y.; et al. Clinical Characteristics of 138 Hospitalized Patients with 2019 Novel Coronavirus-Infected Pneumonia in Wuhan, China. JAMA J. Am. Med. Assoc. 2020, 323, 1061-1069. [CrossRef]

13. Liu, K.; Fang, Y.-Y.; Deng, Y.; Liu, W.; Wang, M.-F.; Ma, J.-P.; Xiao, W.; Wang, Y.-N.; Zhong, M.-H.; Li, C.-H.; et al. Clinical characteristics of novel coronavirus cases in tertiary hospitals in Hubei Province. Chin. Med. J. 2020, 133, 1025-1031. [CrossRef]

14. Xu, X.; Chen, P.; Wang, J.; Feng, J.; Zhou, H.; Li, X.; Zhong, W.; Hao, P. Evolution of the novel coronavirus from the ongoing Wuhan outbreak and modeling of its spike protein for risk of human transmission. Sci. China Life Sci. 2020, 63, 457-460. [CrossRef]

15. Tortorici, M.A.; Veesler, D. Structural insights into coronavirus entry. In Advances in Virus Research; Academic Press Inc.: Cambridge, MA, USA, 2019; Volume 105, pp. 93-116, ISBN 9780128184561.

16. Zhang, N.; Jiang, S.; Du, L. Current advancements and potential strategies in the development of MERS-CoV vaccines. Expert Rev. Vaccines 2014, 13, 761-774. [CrossRef] [PubMed]

17. Li, M.Y.; Li, L.; Zhang, Y.; Wang, X.S. Expression of the SARS-CoV-2 cell receptor gene ACE2 in a wide variety of human tissues. Infect. Dis. Poverty 2020, 9, 45. [CrossRef] [PubMed]

18. Jaimes, J.A.; André, N.M.; Chappie, J.S.; Millet, J.K.; Whittaker, G.R. Phylogenetic Analysis and Structural Modeling of SARS-CoV2 Spike Protein Reveals an Evolutionary Distinct and Proteolytically Sensitive Activation Loop. J. Mol. Biol. 2020, 432, 3309-3325. [CrossRef]

19. Wang, H.; Yuan, X.; Sun, Y.; Mao, X.; Meng, C.; Tan, L.; Song, C.; Qiu, X.; Ding, C.; Liao, Y. Infectious bronchitis virus entry mainly depends on clathrin mediated endocytosis and requires classical endosomal/lysosomal system. Virology 2019, 528, 118-136. [CrossRef] [PubMed]

20. Hagemeijer, M.C.; Monastyrska, I.; Griffith, J.; van der Sluijs, P.; Voortman, J.; van Bergen en Henegouwen, P.M.; Vonk, A.M.; Rottier, P.J.M.; Reggiori, F.; De Haan, C.A.M. Membrane rearrangements mediated by coronavirus nonstructural proteins 3 and 4. Virology 2014, 458-459, 125-135. [CrossRef] [PubMed]

21. Klionsky, D.J.; Abdelmohsen, K.; Abe, A.; Abedin, M.J.; Abeliovich, H.; Arozena, A.A.; Adachi, H.; Adams, C.M.; Adams, P.D.; Adeli, K.; et al. Guidelines for the use and interpretation of assays for monitoring autophagy (3rd edition). Autophagy 2016, 12, 1-222. [CrossRef]

22. Perlman, S.; Netland, J. Coronaviruses post-SARS: Update on replication and pathogenesis. Nat. Rev. Microbiol. 2009, 7, 439-450. [CrossRef]

23. Oudshoorn, D.; Rijs, K.; Limpens, R.W.A.L.; Groen, K.; Koster, A.J.; Snijder, E.J.; Kikkert, M.; Bárcena, M. Expression and cleavage of middle east respiratory syndrome coronavirus nsp3-4 polyprotein induce the formation of double-membrane vesicles that mimic those associated with coronaviral RNA replication. mBio 2017, 8, 1658-1675. [CrossRef]

24. De Haan, C.A.M.; Rottier, P.J.M. Molecular Interactions in the Assembly of Coronaviruses. Adv. Virus Res. 2005, 64, 165-230.

25. Westerbeck, J.W.; Machamer, C.E. A Coronavirus E Protein Is Present in Two Distinct Pools with Different Effects on Assembly and the Secretory Pathway. J. Virol. 2015, 89, 9313-9323. [CrossRef] [PubMed]

26. Rubinsztein, D.C.; Gestwicki, J.E.; Murphy, L.O.; Klionsky, D.J. Potential therapeutic applications of autophagy. Nat. Rev. Drug Discov. 2007, 6, 304-312. [CrossRef]

27. Buratta, S.; Tancini, B.; Sagini, K.; Delo, F.; Chiaradia, E.; Urbanelli, L.; Emiliani, C. Lysosomal Exocytosis, Exosome Release and Secretory Autophagy: The Autophagic- and Endo-Lysosomal Systems Go Extracellular. Int. J. Mol. Sci. 2020, 21, 2576. [CrossRef]

28. Eskelinen, E.L.; Saftig, P. Autophagy: A lysosomal degradation pathway with a central role in health and disease. Biochim. Biophys. Acta Mol. Cell Res. 2009, 1793, 664-673. [CrossRef] [PubMed]

29. Meijer, A.J.; Codogno, P. Autophagy: Regulation and role in disease. Crit. Rev. Clin. Lab. Sci. 2009, 46, 210-240. [CrossRef] [PubMed]

30. Mizushima, N.; Yoshimori, T.; Levine, B. Methods in Mammalian Autophagy Research. Cell 2010, 140, 313-326. [CrossRef]

31. Choi, A.M.K.; Ryter, S.W.; Levine, B. Mechanisms of disease: Autophagy in human health and disease. N. Engl. J. Med. 2013, 368, 651-662. [CrossRef] [PubMed]

32. Jiang, P.; Mizushima, N. Autophagy and human diseases. Cell Res. 2014, 24, 69-79. [CrossRef] [PubMed] 
33. Lawrence, R.E.; Zoncu, R. The lysosome as a cellular centre for signalling, metabolism and quality control. Nat. Cell Biol. 2019, 21, 133-142. [CrossRef]

34. Kim, Y.C.; Guan, K.L. MTOR: A pharmacologic target for autophagy regulation. J. Clin. Investig. 2015, 125, 25-32. [CrossRef]

35. Inoki, K.; Li, Y.; Zhu, T.; Wu, J.; Guan, K.L. TSC2 is phosphorylated and inhibited by Akt and suppresses mTOR signalling. Nat. Cell Biol. 2002, 4, 648-657. [CrossRef]

36. Laplante, M.; Sabatini, D.M. Regulation of mTORC1 and its impact on gene expression at a glance. J. Cell Sci. 2013, 126, 1713-1719. [CrossRef]

37. Gwinn, D.M.; Shackelford, D.B.; Egan, D.F.; Mihaylova, M.M.; Mery, A.; Vasquez, D.S.; Turk, B.E.; Shaw, R.J. AMPK Phosphorylation of Raptor Mediates a Metabolic Checkpoint. Mol. Cell 2008, 30, 214-226. [CrossRef] [PubMed]

38. Ganley, I.G.; Lam, D.H.; Wang, J.; Ding, X.; Chen, S.; Jiang, X. ULK1·ATG13·FIP200 complex mediates mTOR signaling and is essential for autophagy. J. Biol. Chem. 2009, 284, 12297-12305. [CrossRef]

39. Jung, C.H.; Jun, C.B.; Ro, S.H.; Kim, Y.M.; Otto, N.M.; Cao, J.; Kundu, M.; Kim, D.H. ULK-Atg13-FIP200 complexes mediate mTOR signaling to the autophagy machinery. Mol. Biol. Cell 2009, 20, 1992-2003. [CrossRef] [PubMed]

40. He, C.; Klionsky, D.J. Regulation Mechanisms and Signaling Pathways of Autophagy. Annu. Rev. Genet. 2009, 43, 67-93. [CrossRef] [PubMed]

41. He, C.; Levine, B. The Beclin 1 interactome. Curr. Opin. Cell Biol. 2010, 22, 140-149. [CrossRef] [PubMed]

42. Fimia, G.M.; Corazzari, M.; Antonioli, M.; Piacentini, M. Ambra1 at the crossroad between autophagy and cell death. Oncogene 2013, 32, 3311-3318. [CrossRef]

43. Polson, H.E.J.; De Lartigue, J.; Rigden, D.J.; Reedijk, M.; Urbé, S.; Clague, M.J.; Tooze, S.A. Mammalian Atg18 (WIPI2) localizes to omegasome-anchored phagophores and positively regulates LC3 lipidation. Autophagy 2010, 6, 506-522. [CrossRef]

44. Wesselborg, S.; Stork, B. Autophagy signal transduction by ATG proteins: From hierarchies to networks. Cell. Mol. Life Sci. 2015, 72, 4721-4757. [CrossRef] [PubMed]

45. Mizushima, N. Autophagy: Process and function. Genes Dev. 2007, 21, 2861-2873. [CrossRef]

46. Uematsu, M.; Nishimura, T.; Sakamaki, Y.; Yamamoto, H.; Mizushima, N. Accumulation of undegraded autophagosomes by expression of dominant-negative STX17 (syntaxin 17) mutants. Autophagy 2017, 13, 1452-1464. [CrossRef]

47. Jackson, W.T.; Giddings, T.H.; Taylor, M.P.; Mulinyawe, S.; Rabinovitch, M.; Kopito, R.R.; Kirkegaard, K. Subversion of Cellular Autophagosomal Machinery by RNA Viruses. PLoS Biol. 2005, 3, e156. [CrossRef] [PubMed]

48. New, J.; Thomas, S.M. Autophagy-dependent secretion: Mechanism, factors secreted, and disease implications. Autophagy 2019, 15, 1682-1693. [CrossRef]

49. Orvedahl, A.; Alexander, D.; Tallóczy, Z.; Sun, Q.; Wei, Y.; Zhang, W.; Burns, D.; Leib, D.A.; Levine, B. HSV-1 ICP34.5 Confers Neurovirulence by Targeting the Beclin 1 Autophagy Protein. Cell Host Microbe 2007, 1, 23-35. [CrossRef] [PubMed]

50. Levine, B.; Mizushima, N.; Virgin, H.W. Autophagy in immunity and inflammation. Nature 2011, 469, 323-335. [CrossRef] [PubMed]

51. Gannagé, M.; Dormann, D.; Albrecht, R.; Dengjel, J.; Torossi, T.; Rämer, P.C.; Lee, M.; Strowig, T.; Arrey, F.; Conenello, G.; et al. Matrix Protein 2 of Influenza A Virus Blocks Autophagosome Fusion with Lysosomes. Cell Host Microbe 2009, 6, 367-380. [CrossRef]

52. Chen, X.; Wang, K.; Xing, Y.; Tu, J.; Yang, X.; Zhao, Q.; Li, K.; Chen, Z. Coronavirus membrane-associated papain-like proteases induce autophagy through interacting with Beclin1 to negatively regulate antiviral innate immunity. Protein Cell 2014. [CrossRef] [PubMed]

53. Khan, M.A.A.K.; Sany, M.R.U.; Islam, M.S.; Islam, A.B.M.M.K. Epigenetic Regulator miRNA Pattern Differences Among SARS$\mathrm{CoV}$, SARS-CoV-2, and SARS-CoV-2 World-Wide Isolates Delineated the Mystery Behind the Epic Pathogenicity and Distinct Clinical Characteristics of Pandemic COVID-19. Front. Genet. 2020, 11, 765. [CrossRef] [PubMed]

54. Yue, Y.; Nabar, N.R.; Shi, C.S.; Kamenyeva, O.; Xiao, X.; Hwang, I.Y.; Wang, M.; Kehrl, J.H. SARS-Coronavirus Open Reading Frame-3a drives multimodal necrotic cell death. Cell Death Dis. 2018, 9, 1-15. [CrossRef] [PubMed]

55. Shi, B.; Ma, M.; Zheng, Y.; Pan, Y.; Lin, X. mTOR and Beclin1: Two key autophagy-related molecules and their roles in myocardial ischemia/reperfusion injury. J. Cell. Physiol. 2019, 234, 12562-12568. [CrossRef] [PubMed]

56. Orvedahl, A.; MacPherson, S.; Sumpter, R.; Tallóczy, Z.; Zou, Z.; Levine, B. Autophagy Protects against Sindbis Virus Infection of the Central Nervous System. Cell Host Microbe 2010, 7, 115-127. [CrossRef]

57. Ojha, C.R.; Rodriguez, M.; Karuppan, M.K.M.; Lapierre, J.; Kashanchi, F.; El-Hage, N. Toll-like receptor 3 regulates Zika virus infection and associated host inflammatory response in primary human astrocytes. PLoS ONE 2019, 14, e0208543. [CrossRef]

58. Karuppan, M.K.M.; Ojha, C.R.; Rodriguez, M.; Lapierre, J.; Aman, M.J.; Kashanchi, F.; Toborek, M.; Nair, M.; El-Hage, N. Reduced-Beclin1-Expressing Mice Infected with Zika-R103451 and Viral-Associated Pathology during Pregnancy. Viruses 2020, 12, 608. [CrossRef]

59. Nardacci, R.; Amendola, A.; Ciccosanti, F.; Corazzari, M.; Esposito, V.; Vlassi, C.; Taibi, C.; Fimia, G.M.; Del Nonno, F.; Ippolito, G.; et al. Autophagy plays an important role in the containment of HIV-1 in nonprogressor-infected patients. Autophagy 2014, 10, 1167-1178. [CrossRef]

60. Gassen, N.C.; Niemeyer, D.; Muth, D.; Corman, V.M.; Martinelli, S.; Gassen, A.; Hafner, K.; Papies, J.; Mösbauer, K.; Zellner, A.; et al. SKP2 attenuates autophagy through Beclin1-ubiquitination and its inhibition reduces MERS-Coronavirus infection. Nat. Commun. 2019. [CrossRef] 
61. Kindrachuk, J.; Ork, B.; Hart, B.J.; Mazur, S.; Holbrook, M.R.; Frieman, M.B.; Traynor, D.; Johnson, R.F.; Dyall, J.; Kuhn, J.H.; et al. Antiviral potential of ERK/MAPK and PI3K/AKT/mTOR signaling modulation for Middle East respiratory syndrome coronavirus infection as identified by temporal kinome analysis. Antimicrob. Agents Chemother. 2015, 59, 1088-1099. [CrossRef] [PubMed]

62. Mattoscio, D.; Medda, A.; Chiocca, S. Human papilloma virus and autophagy. Int. J. Mol. Sci. 2018, 19, 1775. [CrossRef] [PubMed]

63. Surviladze, Z.; Sterk, R.T.; DeHaro, S.A.; Ozbun, M.A. Cellular Entry of Human Papillomavirus Type 16 Involves Activation of the Phosphatidylinositol 3-Kinase/Akt/mTOR Pathway and Inhibition of Autophagy. J. Virol. 2013, 87, 2508-2517. [CrossRef]

64. Jiang, M.; Ju, M.; Bu, W.; Chen, K.; Li, L.; Li, M.; Chen, X.; Gu, H. HPV Infection Downregulates the Expression of AutophagyRelated Genes in Condylomata Acuminata. Dermatology 2019, 235, 418-425. [CrossRef] [PubMed]

65. Zhou, Z.; Jiang, X.; Liu, D.; Fan, Z.; Hu, X.; Yan, J.; Wang, M.; Gao, G.F. Autophagy is involved in influenza A virus replication. Autophagy 2009, 5, 321-328. [CrossRef]

66. Zhang, X.; Xiong, Y.; Zhang, J.; Shao, T.; Chen, S.; Miao, B.; Wang, Z.; Du, Q.; Huang, Y.; Tong, D. Autophagy promotes porcine parvovirus replication and induces non-apoptotic cell death in porcine placental trophoblasts. Viruses 2019, 12, 15. [CrossRef]

67. Lin, J.Y.; Huang, H.I. Autophagy is induced and supports virus replication in Enterovirus A71-infected human primary neuronal cells. Sci. Rep. 2020, 10, 1-16. [CrossRef]

68. Lee, Y.R.; Lei, H.Y.; Liu, M.T.; Wang, J.R.; Chen, S.H.; Jiang-Shieh, Y.F.; Lin, Y.S.; Yeh, T.M.; Liu, C.C.; Liu, H.S. Autophagic machinery activated by dengue virus enhances virus replication. Virology 2008, 374, 240-248. [CrossRef] [PubMed]

69. Chiramel, A.I.; Best, S.M. Role of autophagy in Zika virus infection and pathogenesis. Virus Res. 2018, 254, 34-40. [CrossRef] [PubMed]

70. Tian, L.; Yang, Y.; Li, C.; Chen, J.; Li, Z.; Li, X.; Li, S.; Wu, F.; Hu, Z.; Yang, Z. The cytotoxicity of coxsackievirus B3 is associated with a blockage of autophagic flux mediated by reduced syntaxin 17 expression article. Cell Death Dis. 2018, 9, 1-12. [CrossRef]

71. Chiramel, A.; Brady, N.; Bartenschlager, R. Divergent Roles of Autophagy in Virus Infection. Cells 2013, 2, 83-104. [CrossRef]

72. Gassen, N.C.; Papies, J.; Bajaj, T.; Dethloff, F.; Emanuel, J.; Weckmann, K.; Heinz, D.E.; Heinemann, N.; Lennarz, M.; Richter, A.; et al. Analysis of SARS-CoV-2-controlled autophagy reveals spermidine, MK-2206, and niclosamide as putative antiviral therapeutics. bioRxiv 2020. [CrossRef]

73. Galluzzi, L.; Baehrecke, E.H.; Ballabio, A.; Boya, P.; Bravo-San Pedro, J.M.; Cecconi, F.; Choi, A.M.; Chu, C.T.; Codogno, P.; Colombo, M.I.; et al. Molecular definitions of autophagy and related processes. EMBO J. 2017, 36, 1811-1836. [CrossRef] [PubMed]

74. Mijaljica, D.; Klionsky, D.J. Autophagy/virophagy: A “disposal strategy” to combat COVID-19. Autophagy 2020, $2271-2272$. [CrossRef] [PubMed]

75. Zhao, Z.; Thackray, L.B.; Miller, B.C.; Lynn, T.M.; Becker, M.M.; Ward, E.; Mizushima, N.N.; Denison, M.R.; Virgin IV, H.W. Coronavirus replication does not require the autophagy gene ATG5. Autophagy 2007, 3, 581-585. [CrossRef] [PubMed]

76. Reggiori, F.; Monastyrska, I.; Verheije, M.H.; Calì, T.; Ulasli, M.; Bianchi, S.; Bernasconi, R.; De Haan, C.A.M.; Molinari, M. Coronaviruses hijack the LC3-I-positive EDEMosomes, ER-derived vesicles exporting short-lived ERAD regulators, for replication. Cell Host Microbe 2010, 7, 500-508. [CrossRef] [PubMed]

77. Schneider, M.; Ackermann, K.; Stuart, M.; Wex, C.; Protzer, U.; Schätzl, H.M.; Gilch, S. Severe Acute Respiratory Syndrome Coronavirus Replication Is Severely Impaired by MG132 due to Proteasome-Independent Inhibition of M-Calpain. J. Virol. 2012, 86, 10112-10122. [CrossRef]

78. Yang, N.; Shen, H.M. Targeting the endocytic pathway and autophagy process as a novel therapeutic strategy in COVID-19. Int. J. Biol. Sci. 2020, 16, 1724-1731. [CrossRef]

79. Benvenuto, D.; Angeletti, S.; Giovanetti, M.; Bianchi, M.; Pascarella, S.; Cauda, R.; Ciccozzi, M.; Cassone, A. Evolutionary analysis of SARS-CoV-2: How mutation of Non-Structural Protein 6 (NSP6) could affect viral autophagy. J. Infect. 2020, 81, e24-e27. [CrossRef] [PubMed]

80. Mercatelli, D.; Holding, A.N.; Giorgi, F.M. Web tools to fight pandemics: The COVID-19 experience. Brief. Bioinform. 2020, 2020, 1-11. [CrossRef] [PubMed]

81. Mercatelli, D.; Giorgi, F.M. Geographic and Genomic Distribution of SARS-CoV-2 Mutations. Front. Microbiol. 2020, 11, 1800. [CrossRef]

82. Bauer, D.C.; Tay, A.P.; Wilson, L.O.W.; Reti, D.; Hosking, C.; McAuley, A.J.; Pharo, E.; Todd, S.; Stevens, V.; Neave, M.J.; et al. Supporting pandemic response using genomics and bioinformatics: A case study on the emergent SARS-CoV-2 outbreak. Transbound. Emerg. Dis. 2020, 67, 1453-1462. [CrossRef]

83. Forster, P.; Forster, L.; Renfrew, C.; Forster, M. Reply to Sánchez-Pacheco et al., Chookajorn, and Mavian et al.: Explaining phylogenetic network analysis of SARSCoV-2 genomes. Proc. Natl. Acad. Sci. USA 2020, 117, 12524-12525. [CrossRef]

84. Cottam, E.M.; Maier, H.J.; Manifava, M.; Vaux, L.C.; Chandra-Schoenfelder, P.; Gerner, W.; Britton, P.; Ktistakis, N.T.; Wileman, T. Coronavirus nsp6 proteins generate autophagosomes from the endoplasmic reticulum via an omegasome intermediate. Autophagy 2011, 7, 1335-1347. [CrossRef] [PubMed]

85. Guo, C.; Tsai, S.J.; Ai, Y.; Li, M.; Pekosz, A.; Cox, A.; Atai, N.; Gould, S.J. The D614G Mutation Enhances the Lysosomal Trafficking of SARS-CoV-2 Spike. bioRxiv 2020. [CrossRef]

86. Kuehn, B.M. Genetic Analysis Tracks SARS-CoV-2 Mutations in Human Hosts. JAMA J. Am. Med. Assoc. 2020, $323,2363$. [CrossRef] [PubMed] 
87. Dearlove, B.; Lewitus, E.; Bai, H.; Li, Y.; Reeves, D.B.; Joyce, M.G.; Scott, P.T.; Amare, M.F.; Vasan, S.; Michael, N.L.; et al. A SARSCoV-2 vaccine candidate would likely match all currently circulating variants. Proc. Natl. Acad. Sci. USA 2020, 117, $23652-23662$. [CrossRef]

88. Schmidt, N.; Lareau, C.A.; Keshishian, H.; Ganskih, S.; Schneider, C.; Hennig, T.; Melanson, R.; Werner, S.; Wei, Y.; Zimmer, M.; et al. The SARS-CoV-2 RNA-protein interactome in infected human cells. Nat. Microbiol. 2020, 1-15. [CrossRef]

89. Gordon, D.E.; Jang, G.M.; Bouhaddou, M.; Xu, J.; Obernier, K.; White, K.M.; O'Meara, M.J.; Rezelj, V.V.; Guo, J.Z.; Swaney, D.L.; et al. A SARS-CoV-2 protein interaction map reveals targets for drug repurposing. Nature 2020, 583, 459-468. [CrossRef] [PubMed]

90. Kliche, J.; Kuss, H.; Ali, M.; Ivarsson, Y. Cytoplasmic short linear motifs in ACE2 and integrin $\beta_{3}$ link SARS-CoV-2 host cell receptors to mediators of endocytosis and autophagy. Sci. Signal. 2021, 14, eabf1117. [CrossRef]

91. Snijder, E.J.; van der Meer, Y.; Zevenhoven-Dobbe, J.; Onderwater, J.J.M.; van der Meulen, J.; Koerten, H.K.; Mommaas, A.M. Ultrastructure and Origin of Membrane Vesicles Associated with the Severe Acute Respiratory Syndrome Coronavirus Replication Complex. J. Virol. 2006, 80, 5927-5940. [CrossRef]

92. Miller, K.; McGrath, M.E.; Hu, Z.; Ariannejad, S.; Weston, S.; Frieman, M.; Jackson, W.T. Coronavirus interactions with the cellular autophagy machinery. Autophagy 2020, 1-9. [CrossRef]

93. Servier Medical Art by Servier Is Licensed under a Creative Commons Attribution 3.0 Unported License. Servier Medical Art. Available online: https:/ / smart.servier.com/ (accessed on 2 January 2021).

94. Cong, Y.; Verlhac, P.; Reggiori, F. The Interaction between Nidovirales and Autophagy Components. Viruses 2017, 9, 182. [CrossRef] [PubMed]

95. Painter, J.D.; Galle-Treger, L.; Akbari, O. Role of Autophagy in Lung Inflammation. Front. Immunol. 2020, 11, 1337. [CrossRef]

96. Pehote, G.; Vij, N. Autophagy Augmentation to Alleviate Immune Response Dysfunction, and Resolve Respiratory and COVID-19 Exacerbations. Cells 2020, 9, 1952. [CrossRef]

97. Jackson, W.T. Viruses and the autophagy pathway. Virology 2015, 479-480, 450-456. [CrossRef]

98. Brest, P.; Benzaquen, J.; Klionsky, D.J.; Hofman, P.; Mograbi, B. Open questions for harnessing autophagy-modulating drugs in the SARS-CoV-2 war: Hope or hype? Autophagy 2020, 1-4. [CrossRef]

99. Shojaei, S.; Suresh, M.; Klionsky, D.J.; Labouta, H.I.; Ghavami, S. Autophagy and SARS-CoV-2 infection: A possible smart targeting of the autophagy pathway. Virulence 2020, 11, 805-810. [CrossRef]

100. Morris, G.; Athan, E.; Walder, K.; Bortolasci, C.C.; O’Neil, A.; Marx, W.; Berk, M.; Carvalho, A.F.; Maes, M.; Puri, B.K. Can endolysosomal deacidification and inhibition of autophagy prevent severe COVID-19? Life Sci. 2020, 262, 118541. [CrossRef]

101. Hoffmann, M.; Kleine-Weber, H.; Schroeder, S.; Krüger, N.; Herrler, T.; Erichsen, S.; Schiergens, T.S.; Herrler, G.; Wu, N.H.; Nitsche, A.; et al. SARS-CoV-2 Cell Entry Depends on ACE2 and TMPRSS2 and Is Blocked by a Clinically Proven Protease Inhibitor. Cell 2020, 181, 271-280.e8. [CrossRef] [PubMed]

102. Bello-Perez, M.; Sola, I.; Novoa, B.; Klionsky, D.J.; Falco, A. Canonical and Noncanonical Autophagy as Potential Targets for COVID-19. Cells 2020, 9, 1619. [CrossRef] [PubMed]

103. Maiese, K. The mechanistic target of rapamycin (mTOR): Novel Considerations as an Antiviral Treatment and Possibilities for COVID-19. Curr. Neurovasc. Res. 2020, 17. [CrossRef]

104. Al-Bari, M.A.A. Targeting endosomal acidification by chloroquine analogs as a promising strategy for the treatment of emerging viral diseases. Pharmacol. Res. Perspect. 2017, 5. [CrossRef]

105. Mauthe, M.; Orhon, I.; Rocchi, C.; Zhou, X.; Luhr, M.; Hijlkema, K.J.; Coppes, R.P.; Engedal, N.; Mari, M.; Reggiori, F. Chloroquine inhibits autophagic flux by decreasing autophagosome-lysosome fusion. Autophagy 2018, 14, 1435-1455. [CrossRef] [PubMed]

106. Vincent, M.J.; Bergeron, E.; Benjannet, S.; Erickson, B.R.; Rollin, P.E.; Ksiazek, T.G.; Seidah, N.G.; Nichol, S.T. Chloroquine is a potent inhibitor of SARS coronavirus infection and spread. Virol. J. 2005, 2, 69. [CrossRef]

107. Savarino, A.; Di Trani, L.; Donatelli, I.; Cauda, R.; Cassone, A. New insights into the antiviral effects of chloroquine. Lancet Infect. Dis. 2006, 6, 67-69. [CrossRef]

108. Wang, M.; Cao, R.; Zhang, L.; Yang, X.; Liu, J.; Xu, M.; Shi, Z.; Hu, Z.; Zhong, W.; Xiao, G. Remdesivir and chloroquine effectively inhibit the recently emerged novel coronavirus (2019-nCoV) in vitro. Cell Res. 2020, 30, 269-271. [CrossRef]

109. Gao, J.; Tian, Z.; Yang, X. Breakthrough: Chloroquine phosphate has shown apparent efficacy in treatment of COVID-19 associated pneumonia in clinical studies. Biosci. Trends 2020, 14, 72-73. [CrossRef] [PubMed]

110. Hoffmann, M.; Mösbauer, K.; Hofmann-Winkler, H.; Kaul, A.; Kleine-Weber, H.; Krüger, N.; Gassen, N.C.; Müller, M.A.; Drosten, C.; Pöhlmann, S. Chloroquine does not inhibit infection of human lung cells with SARS-CoV-2. Nature 2020, 585, 588-590. [CrossRef] [PubMed]

111. Sun, J.; Chen, Y.; Fan, X.; Wang, X.; Han, Q.; Liu, Z. Advances in the use of chloroquine and hydroxychloroquine for the treatment of COVID-19. Postgrad. Med. 2020, 132, 604-613. [CrossRef]

112. Schrezenmeier, E.; Dörner, T. Mechanisms of action of hydroxychloroquine and chloroquine: Implications for rheumatology. Nat. Rev. Rheumatol. 2020, 16, 155-166. [CrossRef] [PubMed]

113. Disbrow, G.L. Letter Revoking EUA for Chloroquine Phosphate and Hydroxychloroquine Sulfate. Available online: https: //www.fda.gov/media/138945/download (accessed on 14 June 2020). 
114. World Health Organization. Solidarity Clinical Trial for COVID-19 Treatments. Available online: https://www.who.int/ emergencies/diseases/novel-coronavirus-2019/global-research-on-novel-coronavirus-2019-ncov/solidarity-clinical-trial-forcovid-19-treatments (accessed on 14 June 2020).

115. Recovery Collaborative Group; Horby, P.; Mafham, M.; Linsell, L.; Bell, J.L.; Staplin, N.; Emberson, J.R.; Wiselka, M.; Ustianowski, A.; Elmahi, E.; et al. Effect of Hydroxychloroquine in Hospitalized Patients with Covid-19. N. Engl. J. Med. 2020, 21, 2030-2070. [CrossRef]

116. Liu, Y.; Yang, Y.; Zhang, C.; Huang, F.; Wang, F.; Yuan, J.; Wang, Z.; Li, J.; Li, J.; Feng, C.; et al. Clinical and biochemical indexes from 2019-nCoV infected patients linked to viral loads and lung injury. Sci. China Life Sci. 2020, 63, 364-374. [CrossRef] [PubMed]

117. Wang, H.; Yang, P.; Liu, K.; Guo, F.; Zhang, Y.; Zhang, G.; Jiang, C. SARS coronavirus entry into host cells through a novel clathrinand caveolae-independent endocytic pathway. Cell Res. 2008, 18, 290-301. [CrossRef]

118. Halfon, P.; Bestion, E.; Zandi, K.; Andreani, J.; Baudoin, J.-P.; La Scola, B.; Mege, J.-L.; Mezouar, S.; Schinazi, R.F. GNS561 exhibits potent in vitro antiviral activity against SARS-CoV-2 through autophagy inhibition. bioRxiv 2020. [CrossRef]

119. U.S. Department of Health \& Human Services. Available online: https:/ / www.clinicaltrials.gov / (accessed on 2 January 2021).

120. Gorshkov, K.; Chen, C.; Bostwick, R.; Rasmussen, L.; Xu, M.; Pradhan, M.; Tran, B.N.; Zhu, W.; Shamim, K.; Huang, W.; et al. The SARS-CoV-2 cytopathic effect is blocked with autophagy modulators. bioRxiv 2020. [CrossRef]

121. Parnham, M.J.; Haber, V.E.; Giamarellos-Bourboulis, E.J.; Perletti, G.; Verleden, G.M.; Vos, R. Azithromycin: Mechanisms of action and their relevance for clinical applications. Pharmacol. Ther. 2014, 143, 225-245. [CrossRef]

122. Gielen, V.; Johnston, S.L.; Edwards, M.R. Azithromycin induces anti-viral responses in bronchial epithelial cells. Eur. Respir. J. 2010, 36, 646-654. [CrossRef]

123. Madrid, P.B.; Panchal, R.G.; Warren, T.K.; Shurtleff, A.C.; Endsley, A.N.; Green, C.E.; Kolokoltsov, A.; Davey, R.; Manger, I.D.; Gilfillan, L.; et al. Evaluation of Ebola Virus Inhibitors for Drug Repurposing. ACS Infect. Dis. 2016, 1, 317-326. [CrossRef] [PubMed]

124. Retallack, H.; Di Lullo, E.; Arias, C.; Knopp, K.A.; Laurie, M.T.; Sandoval-Espinosa, C.; Leon, W.R.M.; Krencik, R.; Ullian, E.M.; Spatazza, J.; et al. Zika virus cell tropism in the developing human brain and inhibition by azithromycin. Proc. Natl. Acad. Sci. USA 2016, 113, 14408-14413. [CrossRef] [PubMed]

125. Tran, D.H.; Sugamata, R.; Hirose, T.; Suzuki, S.; Noguchi, Y.; Sugawara, A.; Ito, F.; Yamamoto, T.; Kawachi, S.; Akagawa, K.S.; et al. Azithromycin, a 15-membered macrolide antibiotic, inhibits influenza A(H1N1)pdm09 virus infection by interfering with virus internalization process. J. Antibiot. 2019, 72, 759-768. [CrossRef]

126. Poschet, J.F.; Perkett, E.A.; Timmins, G.S.; Deretic, V. Azithromycin and ciprofloxacin have a chloroquine-like effect on respiratory epithelial cells. bioRxiv 2020. [CrossRef]

127. Andreani, J.; Le, M.; Du, I.; Jardot, P.; Rolland, C. In vitro testing of combined hydroxychloroquine and azithromycin on SARSCoV-2 shows synergistic effect. Microb. Pathog. J. 2020, 145, 104228. [CrossRef] [PubMed]

128. Fantini, J.; Chahinian, H.; Yahi, N. Synergistic antiviral effect of hydroxychloroquine and azithromycin in combination against SARS-CoV-2: What molecular dynamics studies of virus-host interactions reveal. Int. J. Antimicrob. Agents 2020, 56, 106020. [CrossRef] [PubMed]

129. Gautret, P.; Lagier, J.-C.; Parola, P.; Hoang, V.T.; Meddeb, L.; Mailhe, M.; Doudier, B.; Courjon, J.; Giordanengo, V.; Vieira, V.E.; et al. Hydroxychloroquine and azithromycin as a treatment of COVID-19. Int. J. Antimicrob. Agents 2020, 56, 105949. [CrossRef] [PubMed]

130. Lane, J.C.; Weaver, J.; Kostka, K.; Duarte-Salles, T.; Abrahao, M.T.F.; Alghoul, H.; Alser, O.; Alshammari, T.M.; Biedermann, P.; Burn, E.; et al. Safety of hydroxychloroquine, alone and in combination with azithromycin, in light of rapid wide-spread use for COVID-19: A multinational, network cohort and self-controlled case series study. medRxiv 2020. [CrossRef]

131. Million, M.; Lagier, J.; Gautret, P.; Colson, P.; Fournier, P.; Amrane, S.; Hocquart, M.; Mailhe, M. Early treatment of COVID-19 patients with hydroxychloroquine and azithromycin: A retrospective analysis of 1061 cases in Marseille, France. Travel Med. Infect. Dis. J. 2020, 35, 101738. [CrossRef]

132. Molinaa, J.M.; Delaugerreb, C.; Le Goff, J.; Mela-Lima, B.; Ponscarme, D.; Goldwirte, L.; de Castro, N. No evidence of rapid antiviral clearance or clinical ben- efit with the combination of hydroxychloroquine and azithromycin in patients with severe COVID-19 infection. Méd. Mal. Infect. 2020, 382-387.

133. Gbinigie, K.; Frie, K. Should azithromycin be used to treat COVID-19? A rapid review. BJGP Open 2020. [CrossRef]

134. Wu, R.; Wang, L.; Kuo, H.C.D.; Shannar, A.; Peter, R.; Chou, P.J.; Li, S.; Hudlikar, R.; Liu, X.; Liu, Z.; et al. An Update on Current Therapeutic Drugs Treating COVID-19. Curr. Pharmacol. Rep. 2020, 6, 56-70. [CrossRef]

135. Medhi, B.; Patyar, S.; Rao, R.S.; Byrav DS, P.; Prakash, A. Pharmacokinetic and Toxicological Profile of Artemisinin Compounds: An Update. Pharmacology 2009, 84, 323-332. [CrossRef]

136. Sun, X.; Yan, P.; Zou, C.; Wong, Y.; Shu, Y.; Lee, Y.M.; Zhang, C.; Yang, N.; Wang, J.; Zhang, J. Targeting autophagy enhances the anticancer effect of artemisinin and its derivatives. Med. Res. Rev. 2019, 39, 2172-2193. [CrossRef]

137. Hamacher-Brady, A.; Stein, H.A.; Turschner, S.; Toegel, I.; Mora, R.; Jennewein, N.; Efferth, T.; Eils, R.; Brady, N.R. Artesunate activates mitochondrial apoptosis in breast cancer cells via iron-catalyzed lysosomal reactive oxygen species production. J. Biol. Chem. 2011, 286, 6587-6601. [CrossRef] [PubMed]

138. Guan, X.; Guan, Y. Artemisinin induces selective and potent anticancer effects in drug-resistant breast cancer cells by inducing cellular apoptosis and autophagy and G2/M cell cycle arrest. JBUON 2020, 25, 1330-1336. 
139. Meshnick, S.R. Artemisinin: Mechanisms of action, resistance and toxicity. In Proceedings of the International Journal for Parasitology. Int. J. Parasitol. 2002, 32, 1655-1660. [CrossRef]

140. Efferth, T. Beyond malaria: The inhibition of viruses by artemisinin-type compounds. Biotechnol. Adv. 2018, 36, 1730-1737. [CrossRef] [PubMed]

141. Shi, C.; Li, H.; Yang, Y.; Hou, L. Anti-Inflammatory and Immunoregulatory Functions of Artemisinin and Its Derivatives. Mediat. Inflamm. 2015, 2015, 435713. [CrossRef] [PubMed]

142. Wang, K.S.; Li, J.; Wang, Z.; Mi, C.; Ma, J.; Piao, L.X.; Xu, G.H.; Li, X.; Jin, X. Artemisinin inhibits inflammatory response via regulating NF- $\mathrm{KB}$ and MAPK signaling pathways. Immunopharmacol. Immunotoxicol. 2017, 39, 28-36. [CrossRef]

143. DeDiego, M.L.; Nieto-Torres, J.L.; Regla-Nava, J.A.; Jimenez-Guardeno, J.M.; Fernandez-Delgado, R.; Fett, C.; Castano-Rodriguez, C.; Perlman, S.; Enjuanes, L. Inhibition of NF-B-Mediated Inflammation in Severe Acute Respiratory Syndrome CoronavirusInfected Mice Increases Survival. J. Virol. 2014, 88, 913-924. [CrossRef]

144. Cao, R.; Hu, H.; Li, Y.; Wang, X.; Xu, M.; Liu, J.; Zhang, H.; Yan, Y.; Zhao, L.; Li, W.; et al. Anti-SARS-CoV-2 Potential of Artemisinins In Vitro. ACS Infect. Dis. 2020, 6, 2524-2531. [CrossRef]

145. Lee, H.C.; Aarhus, R. Functional visualization of the separate but interacting calcium stores sensitive to NAADP and cyclic ADP-ribose. J. Cell Sci. 2000, 113, 4413-4420.

146. Patel, S.; Churchill, G.C.; Galione, A. Coordination of $\mathrm{Ca}^{2+}$ signalling by NAADP. Trends Biochem. Sci. 2001, 26, 482-489. [CrossRef]

147. Galione, A. NAADP, a new intracellular messenger that mobilizes $\mathrm{Ca}^{2+}$ from acidic stores. Biochem. Soc. Trans. 2006, 34, 922-926. [CrossRef]

148. Ruas, M.; Rietdorf, K.; Arredouani, A.; Davis, L.C.; Lloyd-Evans, E.; Koegel, H.; Funnell, T.M.; Morgan, A.J.; Ward, J.A.; Watanabe, K.; et al. Purified TPC Isoforms Form NAADP Receptors with Distinct Roles for $\mathrm{Ca}^{2+}$ Signaling and Endolysosomal Trafficking. Curr. Biol. 2010, 20, 703-709. [CrossRef] [PubMed]

149. Brailoiu, E.; Churamani, D.; Cai, X.; Schrlau, M.G.; Brailoiu, G.C.; Gao, X.; Hooper, R.; Boulware, M.J.; Dun, N.J.; Marchant, J.S.; et al. Essential requirement for two-pore channel 1 in NAADP-mediated calcium signaling. J. Cell Biol. 2009, 186, 201-209. [CrossRef]

150. Calcraft, P.J.; Ruas, M.; Pan, Z.; Cheng, X.; Arredouani, A.; Hao, X.; Tang, J.; Rietdorf, K.; Teboul, L.; Chuang, K.-T.; et al. NAADP mobilizes calcium from acidic organelles through two-pore channels. Nature 2009, 459, 596-600. [CrossRef] [PubMed]

151. Pereira, G.J.S.; Hirata, H.; Fimia, G.M.; Do Carmo, L.G.; Bincoletto, C.; Han, S.W.; Stilhano, R.S.; Ureshino, R.P.; Bloor-Young, D.; Churchill, G.; et al. Nicotinic Acid Adenine Dinucleotide Phosphate (NAADP) regulates autophagy in cultured astrocytes. J. Biol. Chem. 2011, 286, 27875-27881. [CrossRef] [PubMed]

152. Pereira, G.J.S.; Antonioli, M.; Hirata, H.; Ureshino, R.P.; Nascimento, A.R.; Bincoletto, C.; Vescovo, T.; Piacentini, M. Glutamate induces autophagy via the two-pore channels in neural cells. Oncotarget 2017, 8, 12730-12740. [CrossRef] [PubMed]

153. Pereira, G.J.S.; Hirata, H.; do Carmo, L.G.; Stilhano, R.S.; Ureshino, R.P.; Medaglia, N.C.; Han, S.W.; Churchill, G.; Bincoletto, C.; Patel, S.; et al. NAADP-sensitive two-pore channels are present and functional in gastric smooth muscle cells. Cell Calcium 2014, 56, 51-58. [CrossRef]

154. Gómez-Suaga, P.; Luzón-Toro, B.; Churamani, D.; Zhang, L.; Bloor-Young, D.; Patel, S.; Woodman, P.G.; Churchill, G.C.; Hilfiker, S. Leucine-rich repeat kinase 2 regulates autophagy through a calcium-dependent pathway involving NAADP. Hum. Mol. Genet. 2012, 21, 511-525. [CrossRef]

155. Rah, S.; Lee, Y.; Kim, U. NAADP-mediated $\mathrm{Ca}^{2+}$ signaling promotes autophagy and protects against LPS-induced liver injury. FASEB J. 2017, 31, 3126-3137. [CrossRef]

156. Ogunbayo, O.A.; Duan, J.; Xiong, J.; Wang, Q.; Feng, X.; Ma, J.; Zhu, M.X.; Evans, A.M. MTORC1 controls lysosomal Ca ${ }^{2+}$ release through the two-pore channel TPC2. Sci. Signal. 2018, 11, 5775. [CrossRef] [PubMed]

157. Simmons, J.A.; D’Souza, R.S.; Ruas, M.; Galione, A.; Casanova, J.E.; White, J.M. Ebolavirus Glycoprotein Directs Fusion through NPC1 + Endolysosomes. J. Virol. 2016, 90, 605-610. [CrossRef]

158. Penny, C.J.; Vassileva, K.; Jha, A.; Yuan, Y.; Chee, X.; Yates, E.; Mazzon, M.; Kilpatrick, B.S.; Muallem, S.; Marsh, M.; et al. Mining of Ebola virus entry inhibitors identifies approved drugs as two-pore channel pore blockers. Biochim. Biophys. Acta Mol. Cell Res. 2019, 1866, 1151-1161. [CrossRef]

159. Côté, M.; Misasi, J.; Ren, T.; Bruchez, A.; Lee, K.; Filone, C.M.; Hensley, L.; Li, Q.; Ory, D.; Chandran, K.; et al. Small molecule inhibitors reveal Niemann-Pick C1 is essential for Ebola virus infection. Nature 2011, 477, 344-348. [CrossRef] [PubMed]

160. Gunaratne, G.S.; Yang, Y.; Li, F.; Walseth, T.F.; Marchant, J.S. NAADP-dependent $\mathrm{Ca}^{2+}$ signaling regulates Middle East respiratory syndrome-coronavirus pseudovirus translocation through the endolysosomal system. Cell Calcium 2018. [CrossRef]

161. Iqbal, N.; Iqbal, N. Imatinib: A Breakthrough of Targeted Therapy in Cancer. Chemother. Res. Pract. 2014, 2014, 357027. [CrossRef]

162. Sisk, J.M.; Frieman, M.B.; Machamer, C.E. Coronavirus S protein-induced fusion is blocked prior to hemifusion by Abl kinase inhibitors. J. Gen. Virol. 2018, 99, 619-630. [CrossRef]

163. García, M.; Cooper, A.; Shi, W.; Bornmann, W.; Carrion, R.; Kalman, D.; Nabel, G.J. Productive replication of ebola virus is regulated by the c-Abl1 tyrosine kinase. Sci. Transl. Med. 2012, 4, 123ra24. [CrossRef] [PubMed]

164. Coleman, C.M.; Sisk, J.M.; Mingo, R.M.; Nelson, E.A.; White, J.M.; Frieman, M.B. Abelson Kinase Inhibitors Are Potent Inhibitors of Severe Acute Respiratory Syndrome Coronavirus and Middle East Respiratory Syndrome Coronavirus Fusion. J. Virol. 2016, 90, 8924-8933. [CrossRef] 
165. Nabavi, S.F.; Habtemariam, S.; Clementi, E.; Berindan-Neagoe, I.; Cismaru, C.A.; Rasekhian, M.; Banach, M.; Izadi, M.; Bagheri, M.; Bagheri, M.S.; et al. Lessons learned from SARS-CoV and MERS-CoV: FDA-approved Abelson tyrosine-protein kinase 2 inhibitors may help us combat SARS-CoV-2. Arch. Med. Sci. 2020, 16, 519-521. [CrossRef] [PubMed]

166. Morales-Ortega, A.; Bernal-Bello, D.; Llarena-Barroso, C.; Frutos-Pérez, B.; Duarte-Millán, M.Á.; de Viedma-García, V.G.; FarfánSedano, A.I.; Canalejo-Castrillero, E.; Ruiz-Giardin, J.M.; Ruiz-Ruiz, J.; et al. Imatinib for COVID-19: A case report. Clin. Immunol. 2020, 218, 108518. [CrossRef] [PubMed]

167. Blaess, M.; Kaiser, L.; Sauer, M.; Csuk, R.; Deigner, H.P. COVID-19/SARS-CoV-2 infection: Lysosomes and lysosomotropism implicate new treatment strategies and personal risks. Int. J. Mol. Sci. 2020, 21, 4953. [CrossRef] [PubMed]

168. Encinar, J.S.; Menendez, J.A. Potential Drugs Targeting Early Innate Immune Evasion of SARS-Coronavirus 2 via 2'-O-Methylation of Viral RNA. Viruses 2020, 12, 525. [CrossRef] [PubMed]

169. Norinder, U.; Tuck, A.; Norgren, K.; Munic Kos, V. Existing highly accumulating lysosomotropic drugs with potential for repurposing to target COVID-19. Biomed. Pharmacother. 2020, 130, 110582. [CrossRef]

170. Sauvat, A.; Ciccosanti, F.; Colavita, F.; Di Rienzo, M.; Castilletti, C.; Capobianchi, M.R.; Kepp, O.; Zitvogel, L.; Fimia, G.M.; Piacentini, M.; et al. On-target versus off-target effects of drugs inhibiting the replication of SARS-CoV-2. Cell Death Dis. 2020, 11. [CrossRef] [PubMed]

171. Gorkin, L.; Kantarjian, H. Targeted therapy: Generic imatinib-impact on frontline and salvage therapy for CML. Nat. Rev. Clin. Oncol. 2016, 13, 270-272. [CrossRef] [PubMed]

172. Joensuu, H.; Dematteo, R.P. The management of gastrointestinal stromal tumors: A model for targeted and multidisciplinary therapy of malignancy. Annu. Rev. Med. 2012, 63, 247-258. [CrossRef] [PubMed]

173. Rahman, N.; Basharat, Z.; Yousuf, M.; Castaldo, G.; Rastrelli, L.; Khan, H. Virtual Screening of Natural Products against Type II Transmembrane Serine Protease (TMPRSS2), the Priming Agent of Coronavirus 2 (SARS-CoV-2). Molecules 2020, 25, 2271. [CrossRef] [PubMed]

174. McKee, D.L.; Sternberg, A.; Stange, U.; Laufer, S.; Naujokat, C. Candidate drugs against SARS-CoV-2 and COVID-19. Pharmacol. Res. 2020, 157, 104859. [CrossRef]

175. Zhou, Y.; Vedantham, P.; Lu, K.; Agudelo, J.; Carrion, R.; Nunneley, J.W.; Barnard, D.; Pöhlmann, S.; McKerrow, J.H.; Renslo, A.R.; et al. Protease inhibitors targeting coronavirus and filovirus entry. Antivir. Res. 2015, 116, 76-84. [CrossRef]

176. Barlow, A.; Landolf, K.M.; Barlow, B.; Yeung, S.Y.A.; Heavner, J.J.; Claassen, C.W.; Heavner, M.S. Review of Emerging Pharmacotherapy for the Treatment of Coronavirus Disease 2019. Pharmacotherapy 2020, 40, 416-437. [CrossRef]

177. Chan, J.F.W.; Yao, Y.; Yeung, M.L.; Deng, W.; Bao, L.; Jia, L.; Li, F.; Xiao, C.; Gao, H.; Yu, P.; et al. Treatment with lopinavir/ritonavir or interferon- $\beta 1 \mathrm{~b}$ improves outcome of MERSCoV infection in a nonhuman primate model of common marmoset. J. Infect. Dis. 2015, 212, 1904-1913. [CrossRef] [PubMed]

178. Cao, B.; Wang, Y.; Wen, D.; Liu, W.; Wang, J.; Fan, G.; Ruan, L.; Song, B.; Cai, Y.; Wei, M.; et al. A trial of lopinavir-ritonavir in adults hospitalized with severe covid-19. N. Engl. J. Med. 2020, 382, 1787-1799. [CrossRef] [PubMed]

179. Boriskin, Y.S.; Leneva, I.A.; Pécheur, E.-I.; Polyak, S.J. Arbidol: A Broad-Spectrum Antiviral Compound that Blocks Viral Fusion. Curr. Med. Chem. 2008, 15, 997-1005. [CrossRef]

180. Boriskin, Y.S.; Pécheur, E.I.; Polyak, S.J. Arbidol: A broad-spectrum antiviral that inhibits acute and chronic HCV infection. Virol. J. 2006, 3. [CrossRef] [PubMed]

181. Hallam, H.J.; Hallam, S.; Rodriguez, S.E.; Barrett, A.D.T.; Beasley, D.W.C.; Chua, A.; Ksiazek, T.G.; Milligan, G.N.; Sathiyamoorthy, V.; Reece, L.M. Baseline mapping of Lassa fever virology, epidemiology and vaccine research and development review-article. NPJ Vaccines 2018, 3. [CrossRef] [PubMed]

182. Hulseberg, C.E.; Fénéant, L.; Szyman'ska, K.M.; Szyman'ska-De Wijs, S.; Kessler, N.P.; Nelson, E.A.; Shoemaker, C.J.; Schmaljohn, C.S.; Polyak, S.J.; White, J.M.; et al. Arbidol and Other Low-Molecular-Weight Drugs That Inhibit Lassa and Ebola Viruses Downloaded from. J. Virol. 2019, 93. [CrossRef] [PubMed]

183. Blaising, J.; Polyak, S.J.; Pécheur, E.I. Arbidol as a broad-spectrum antiviral: An update. Antivir. Res. 2014, 107, 84-94. [CrossRef] [PubMed]

184. Zhou, N.; Pan, T.; Zhang, J.; Li, Q.; Zhang, X.; Bai, C.; Huang, F.; Peng, T.; Zhang, J.; Liu, C.; et al. Glycopeptide antibiotics potently inhibit cathepsin 1 in the late endosome/lysosome and block the entry of ebola virus, middle east respiratory syndrome coronavirus (MERS-CoV), and severe acute respiratory syndrome coronavirus (SARS-CoV). J. Biol. Chem. 2016, 291, 9218-9232. [CrossRef]

185. Zhang, J.; Ma, X.; Yu, F.; Liu, J.; Zou, F.; Pan, T.; Zhang, H. Teicoplanin potently blocks the cell entry of 2019-nCoV. bioRxiv 2020. [CrossRef]

186. Pandrea, I.; Landay, A.L. Implications for Therapy. In Models of Protection Against HIV/SIV; Elsevier Inc.: Amsterdam, The Netherlands, 2012; pp. 81-132, ISBN 9780123877154.

187. Ko, S.; Gu, M.J.; Kim, C.G.; Kye, Y.C.; Lim, Y.; Lee, J.E.; Park, B.C.; Chu, H.; Han, S.H.; Yun, C.H. Rapamycin-induced autophagy restricts porcine epidemic diarrhea virus infectivity in porcine intestinal epithelial cells. Antivir. Res. 2017, 146, 86-95. [CrossRef]

188. Guo, L.; Yu, H.; Gu, W.; Luo, X.; Li, R.; Zhang, J.; Xu, Y.; Yang, L.; Shen, N.; Feng, L.; et al. Autophagy Negatively Regulates Transmissible Gastroenteritis Virus Replication. Sci. Rep. 2016, 6, 1-14. [CrossRef] [PubMed]

189. Yuen, C.; Wong, W.; Mak, L.; Wang, X.; Chu, H.; Yuen, K.; Kok, K. Suppression of SARS-CoV-2 infection in ex-vivo human lung tissues by targeting class III phosphoinositide 3-kinase. J. Med. Virol. 2020, jmv.26583. [CrossRef] [PubMed] 
190. Appelberg, S.; Gupta, S.; Akusjärvi, S.S.; Ambikan, A.T.; Mikaeloff, F.; Saccon, E.; Végvári, Á.; Benfeitas, R.; Sperk, M.; Ståhlberg, M.; et al. Dysregulation in Akt/mTOR/HIF-1 signaling identified by proteo-transcriptomics of SARS-CoV-2 infected cells. Emerg. Microbes Infect. 2020, 9, 1-36. [CrossRef] [PubMed]

191. Shukla, D.; Spear, P.G. Herpesviruses and heparan sulfate: An intimate relationship in aid of viral entry. J. Clin. Investig. 2001, 108, 503-510. [CrossRef]

192. Basu, A.; Kanda, T.; Beyene, A.; Saito, K.; Meyer, K.; Ray, R. Sulfated Homologues of Heparin Inhibit Hepatitis C Virus Entry into Mammalian Cells. J. Virol. 2007, 81, 3933-3941. [CrossRef]

193. Ghezzi, S.; Cooper, L.; Rubio, A.; Pagani, I.; Rosaria, M.; Ippolito, G.; Pelletier, J.; Yates, E.A.; Vicenzi, E. Heparin prevents Zika virus induced-cytopathic effects in human neural progenitor cells Silvia. Antivir. Res. 2020, 140, 13-17. [CrossRef]

194. Vicenzi, E.; Canducci, F.; Pinna, D.; Mancini, N.; Carletti, S.; Lazzarin, A.; Bordignon, C.; Poli, G.; Clementi, M. Coronaviridae and SARS-associated Coronavirus Strain HSR1. Emerg. Infect. Dis. 2004, 10, 413-418. [CrossRef]

195. Sardu, C.; Gambardella, J.; Morelli, M.B.; Wang, X.; Marfella, R.; Santulli, G. Hypertension, Thrombosis, Kidney Failure, and Diabetes: Is COVID-19 an Endothelial Disease? A Comprehensive Evaluation of Clinical and Basic Evidence. J. Clin. Med. 2020, 9, 1417. [CrossRef]

196. Lang, J.; Yang, N.; Deng, J.; Liu, K.; Yang, P.; Zhang, G.; Jiang, C. Inhibition of SARS pseudovirus cell entry by lactoferrin binding to heparan sulfate proteoglycans. PLoS ONE 2011, 6, e23710. [CrossRef]

197. Mycroft-West, C.J.; Su, D.; Pagani, I.; Rudd, T.R.; Elli, S.; Guimond, S.E.; Miller, G.; Meneghetti, M.C.Z.; Nader, H.B.; Li, Y.; et al Heparin inhibits cellular invasion by SARS-CoV-2: Structural dependence of the interaction of the surface protein (spike) S1 receptor binding domain with heparin. bioRxiv 2020. [CrossRef]

198. Vandewalle, J.; Luypaert, A.; De Bosscher, K.; Libert, C. Therapeutic Mechanisms of Glucocorticoids. Trends Endocrinol. Metab. 2018, 29, 42-54. [CrossRef] [PubMed]

199. Sundahl, N.; Bridelance, J.; Libert, C.; De Bosscher, K.; Beck, I.M. Selective glucocorticoid receptor modulation: New directions with non-steroidal scaffolds. Pharmacol. Ther. 2015, 152, 28-41. [CrossRef]

200. Russell, C.D.; Millar, J.E.; Baillie, J.K. Clinical evidence does not support corticosteroid treatment for 2019-nCoV lung injury. Lancet 2020, 395, 473-475. [CrossRef]

201. Zhang, W.; Zhao, Y.; Zhang, F.; Wang, Q.; Li, T.; Liu, Z.; Wang, J.; Qin, Y.; Zhang, X.; Yan, X.; et al. The use of anti-inflammatory drugs in the treatment of people with severe coronavirus disease 2019 (COVID-19): The Perspectives of clinical immunologists from China. Clin. Immunol. 2020, 214, 108393. [CrossRef]

202. Bhaskar, S.; Sinha, A.; Banach, M.; Mittoo, S.; Weissert, R.; Kass, J.S.; Rajagopal, S.; Pai, A.R.; Kutty, S. Cytokine Storm in COVID19-Immunopathological Mechanisms, Clinical Considerations, and Therapeutic Approaches: The REPROGRAM Consortium Position Paper. Front. Immunol. 2020, 11, 1648. [CrossRef] [PubMed]

203. Crosby, J.C.; Heimann, M.A.; Burleson, S.L.; Anzalone, B.C.; Swanson, J.F.; Wallace, D.W.; Greene, C.J. COVID-19: A review of therapeutics under investigation. J. Am. Coll. Emerg. Physicians Open 2020, 1, 231-237. [CrossRef]

204. Favalli, E.G.; Ingegnoli, F.; Cimaz, R.; Caporali, R.; DeLucia, O.; Cincinelli, G. COVID-19 infection and rheumatoid arthritis: Faraway, so close! Autoimmun. Rev. J. 2020, 19, 102523. [CrossRef] [PubMed]

205. Yamaya, M.; Nishimura, H.; Deng, X.; Sugawara, M.; Watanabe, O.; Nomura, K.; Shimotai, Y.; Momma, H.; Ichinose, M.; Kawase, T. Inhibitory effects of glycopyrronium, formoterol, and budesonide on coronavirus HCoV-229E replication and cytokine production by primary cultures of human nasal and tracheal epithelial cells. Respir. Investig. 2020, 58, 155-168. [CrossRef] [PubMed]

206. Kim, S.R.; Song, J.H.; Ahn, J.H.; Lee, G.S.; Ahn, H.; Yoon, S.-I.; Kang, S.G.; Kim, P.H.; Jeon, S.M.; Choi, E.J.; et al. Antiviral and anti-inflammatory activity of budesonide against human rhinovirus infection mediated via autophagy activation. Antivir. Res. 2018, 151, 87-96. [CrossRef]

207. Lee, J.; Kim, S.; Song, J.; Lee, Y.; Ko, H. Anti-Human Rhinovirus 1B Activity of Dexamethasone via GCR-Dependent Autophagy Activation Jae-Sug. Osong Public Health Res. Perspect. 2012, 9, 334. [CrossRef]

208. He, Q.; Song, X.; Huang, Y.; Huang, W.; Ye, B.; Luo, H.; Luo, H.; Wu, L.; Wang, Z.; Chen, W.X.; et al. Dexamethasone stimulates hepatitis B virus (HBV) replication through autophagy. Med. Sci. Monit. 2018, 24, 4617-4624. [CrossRef] [PubMed]

209. Gao, Y.; Zhu, H.; Yang, F.; Wang, Q.; Feng, Y.; Zhang, C. Glucocorticoid-activated IRE1 $\alpha /$ XP-1s signaling: An autophagyassociated protective pathway against endotheliocyte damage. Am. J. Physiol. Cell Physiol. 2018, 315, C300-C309. [CrossRef]

210. Ahn, S.; Park, J.; An, I.; Jung, S.J.; Hwang, J. Transient Receptor Potential cation channel V1 (TRPV1) is degraded by starvationand glucocorticoid-mediated autophagy. Mol. Cells 2014, 37, 257-263. [CrossRef] [PubMed]

211. Troncoso, R.; Paredes, F.; Parra, V.; Gatica, D.; Vásquez-Trincado, C.; Quiroga, C.; Bravo-Sagua, R.; López-Crisosto, C.; Rodriguez, A.E.; Oyarzuń, A.P.; et al. Dexamethasone-induced autophagy mediates muscle atrophy through mitochondrial clearance. Cell Cycle 2014, 13, 2281-2295. [CrossRef]

212. Kar, R.; Riquelme, M.A.; Hua, R.; Jiang, J.X. Glucocorticoid-Induced Autophagy Protects Osteocytes Against Oxidative Stress Through Activation of MAPK/ERK Signaling. JBMR Plus 2019, 3, e10077. [CrossRef]

213. Juszczak, G.R.; Stankiewicz, A.M. Glucocorticoids, genes and brain function. Prog. Neuro-Psychopharmacol. Biol. Psychiatry 2018, 82, 136-168. [CrossRef] 
214. Di Rienzo, M.; Antonioli, M.; Fusco, C.; Liu, Y.; Mari, M.; Orhon, I.; Refolo, G.; Germani, F.; Corazzari, M.; Romagnoli, A.; et al. Autophagy induction in atrophic muscle cells requires ULK1 activation by TRIM32 through unanchored K63-linked polyubiquitin chains. Sci. Adv. 2019, 5, 8857-8865. [CrossRef] [PubMed]

215. Peters, M.C.; Sajuthi, S.; Deford, P.; Christenson, S.; Rios, C.L.; Montgomery, M.T.; Woodruff, P.G.; Mauger, D.T.; Erzurum, S.C.; Johansson, M.W.; et al. COVID-19-related genes in sputum cells in asthma: Relationship to demographic features and corticosteroids. Am. J. Respir. Crit. Care Med. 2020, 202, 83-90. [CrossRef]

216. Finney, L.J.; Glanville, N.; Farne, H.; Aniscenko, J.; Fenwick, P.; Kemp, S.V.; Trujillo-Torralbo, M.B.; Loo, S.L.; Calderazzo, M.A.; Wedzicha, J.A.; et al. Inhaled corticosteroids downregulate the SARS-CoV-2 receptor ACE2 in COPD through suppression of type I interferon. J. Allergy Clin. Immunol. 2020. [CrossRef]

217. Bunyavanich, S.; Do, A.; Vicencio, A. Nasal Gene Expression of Angiotensin-Converting Enzyme 2 in Children and Adults. JAMA 2020, 323, 2427. [CrossRef]

218. Cattrini, C.; Bersanelli, M.; Latocca, M.M.; Conte, B.; Vallome, G.; Boccardo, F. Sex hormones and hormone therapy during covid-19 pandemic: Implications for patients with cancer. Cancers 2020, 12, 2325. [CrossRef]

219. Oudit, G.Y.; Pfeffer, M.A. Plasma angiotensin-converting enzyme 2: Novel biomarker in heart failure with implications for COVID-19. Eur. Heart J. 2020, 41, 1818-1820. [CrossRef] [PubMed]

220. Sama, I.E.; Ravera, A.; Santema, B.T.; Van Goor, H.; Ter Maaten, J.M.; Cleland, J.G.F.; Rienstra, M.; Friedrich, A.W.; Samani, N.J.; $\mathrm{Ng}$, L.L.; et al. Circulating plasma concentrations of angiotensin-converting enzyme 2 inmen and women with heart failure and effects of renin-angiotensin-aldosterone inhibitors. Eur. Heart J. 2020, 41, 1810-1817. [CrossRef]

221. Piccinni, M.P.; Giudizi, M.G.; Biagiotti, R.; Beloni, L.; Giannarini, L.; Sampognaro, S.; Parronchi, P.; Manetti, R.; Annunziato, F.; Livi, C. Progesterone favors the development of human T helper cells producing Th2-type cytokines and promotes both IL-4 production and membrane CD30 expression in established Th1 cell clones. J. Immunol. 1995, 155, 128-133. [PubMed]

222. Stilhano, R.S.; Costa, A.J.; Nishino, M.S.; Shams, S.; Bartolomeo, C.S.; Breithaupt-Faloppa, A.C.; Silva, E.A.; Ramirez, A.L.; Prado, C.M.; Ureshino, R.P. SARS-CoV-2 and the possible connection to ERs, ACE2, and RAGE: Focus on susceptibility factors. FASEB J. 2020, 34, 14103-14119. [CrossRef]

223. Stelzig, K.E.; Canepa-Escaro, F.; Schiliro, M.; Berdnikovs, S.; Prakash, Y.S.; Chiarella, S.E. Estrogen regulates the expression of SARS-CoV-2 receptor ACE2 in differentiated airway epithelial cells. Am. J. Physiol. Lung Cell. Mol. Physiol. 2020, 318, $1280-1281$. [CrossRef] [PubMed]

224. Mariana, R.; Lemes, R.; Jardim, A.; Cynthia, C.; Bartolomeo, S.; Bassani, T.B.; Nishino, M.S.; Jose, G.; Pereira, S.; Soubhi, S.; et al. 17ß-estradiol reduces SARS-CoV-2 infection in vitro. Physiol. Rep. 2021, 9, e14707. [CrossRef]

225. Pozzilli, P.; Lenzi, A. Testosterone, a key hormone in the context of COVID-19 pandemic. Metabolism 2020, 108, 154252. [CrossRef]

226. Salonia, A.; Corona, G.; Giwercman, A.; Maggi, M.; Minhas, S.; Nappi, R.E.; Sofikitis, N.; Vignozzi, L. SARS-CoV-2, testosterone and frailty in males (PROTEGGIMI): A multidimensional research project. Andrology 2020, 9, 19-22. [CrossRef]

227. Klein, S.L.; Flanagan, K.L. Sex differences in immune responses. Nat. Rev. Immunol. 2016, 16, 626-638. [CrossRef]

228. Lin, B.; Ferguson, C.; White, J.T.; Wang, S.; Vessella, R.; True, L.D.; Hood, L.; Nelson, P.S. Prostate-localized and androgen-regulated expression of the membrane- bound serine protease TMPRSS2. Cancer Res. 1999, 59, 4180-4184.

229. Lucas, J.M.; Heinlein, C.; Kim, T.; Hernandez, S.A.; Malik, M.S.; True, L.D.; Morrissey, C.; Corey, E.; Montgomery, B.; Mostaghel, E.; et al. The androgen-regulated protease TMPRSS2 activates a proteolytic cascade involving components of the tumor microenvironment and promotes prostate cancer metastasis. Cancer Discov. 2014, 4, 1310-1325. [CrossRef]

230. Stopsack, K.H.; Mucci, L.A.; Antonarakis, E.S.; Nelson, P.S.; Kantoff, P.W. TMPRSS2 and COVID-19: Serendipity or opportunity for intervention? Cancer Discov. 2020, 10, 779-782. [CrossRef]

231. Horby, P.; Lim, W.S.; Emberson, J.R.; Mafham, M.; Bell, J.L.; Linsell, L.; Phil, D.; Sta-Plin, N.; Brightling, C.; Med, F.; et al. Dexamethasone in Hospitalized Patients with Covid-19-Preliminary Report. N. Engl. J. Med. 2020. [CrossRef]

232. Zou, Z.; Yan, Y.; Shu, Y.; Gao, R.; Sun, Y.; Li, X.; Ju, X.; Liang, Z.; Liu, Q.; Zhao, Y.; et al. Angiotensin-converting enzyme 2 protects from lethal avian influenza A H5N1 infections. Nat. Commun. 2014, 5, 1-7. [CrossRef] [PubMed]

233. Huang, F.; Guo, J.; Zou, Z.; Liu, J.; Cao, B.; Zhang, S.; Li, H.; Wang, W.; Sheng, M.; Liu, S.; et al. Angiotensin II plasma levels are linked to disease severity and predict fatal outcomes in H7N9-infected patients. Nat. Commun. 2014, 5, 3595. [CrossRef] [PubMed]

234. Liu, Y.; Huang, F.; Xu, J.; Yang, P.; Qin, Y.; Cao, M.; Wang, Z.; Li, X.; Zhang, S.; Ye, L.; et al. Anti-hypertensive Angiotensin II receptor blockers associated to mitigation of disease severity in elderly COVID-19 patients. medRxiv 2020. [CrossRef]

235. Xu, H.; Zhong, L.; Deng, J.; Peng, J.; Dan, H.; Zeng, X.; Li, T.; Chen, Q. High expression of ACE2 receptor of 2019-nCoV on the epithelial cells of oral mucosa. Int. J. Oral Sci. 2020, 12, 1-5. [CrossRef]

236. Porrello, E.R.; D’Amore, A.; Curl, C.L.; Allen, A.M.; Harrap, S.B.; Thomas, W.G.; Delbridge, L.M.D. Angiotensin II Type 2 Receptor Antagonizes Angiotensin II Type 1 Receptor-Mediated Cardiomyocyte Autophagy. Hypertension 2009, 53, 1032-1040. [CrossRef] [PubMed]

237. Porrello, E.R.; Delbridge, L.M.D. Cardiomyocyte autophagy is regulated by angiotensin II type 1 and type 2 receptors. Autophagy 2009, 5, 1215-1216. [CrossRef]

238. Zhang, X.; Zheng, J.; Yan, Y.; Ruan, Z.; Su, Y.; Wang, J.; Huang, H.; Zhang, Y.; Wang, W.; Gao, J.; et al. Angiotensin-converting enzyme 2 regulates autophagy in acute lung injury through AMPK/mTOR signaling. Arch. Biochem. Biophys. 2019, 672, 108061. [CrossRef] [PubMed] 
239. Zhang, P.; Zhu, L.; Cai, J.; Lei, F.; Qin, J.J.; Xie, J.; Liu, Y.M.; Zhao, Y.C.; Huang, X.; Lin, L.; et al. Association of Inpatient Use of Angiotensin-Converting Enzyme Inhibitors and Angiotensin II Receptor Blockers with Mortality among Patients with Hypertension Hospitalized with COVID-19. Circ. Res. 2020, 126, 1671-1681. [CrossRef]

240. Harvey, D.J.; Samara, E.; Mechoulam, R. Comparative metabolism of cannabidiol in dog, rat and man. Pharmacol. Biochem. Behav. 1991, 40, 523-532. [CrossRef]

241. Malfait, A.M.; Gallily, R.; Sumariwalla, P.F.; Malik, A.S.; Andreakos, E.; Mechoulam, R.; Feldmann, M. The nonpsychoactive cannabis constituent cannabidiol is an oral anti-arthritic therapeutic in murine collagen-induced arthritis. Proc. Natl. Acad. Sci. USA 2000, 97, 9561-9566. [CrossRef]

242. Capasso, R.; Borrelli, F.; Aviello, G.; Romano, B.; Scalisi, C.; Capasso, F.; Izzo, A.A. Cannabidiol, extracted from Cannabis sativa, selectively inhibits inflammatory hypermotility in mice. Br. J. Pharmacol. 2008, 154, 1001-1008. [CrossRef]

243. Esposito, G.; Scuderi, C.; Valenza, M.; Togna, G.I.; Latina, V.; de Filippis, D.; Cipriano, M.; Carratù, M.R.; Iuvone, T.; Steardo, L. Cannabidiol reduces $\mathrm{A} \beta$-induced neuroinflammation and promotes hippocampal neurogenesis through PPAR $\gamma$ involvement. PLoS ONE 2011, 6, e28668. [CrossRef]

244. Ribeiro, A.; Almeida, V.I.; Costola-De-Souza, C.; Ferraz-De-Paula, V.; Pinheiro, M.L.; Vitoretti, L.B.; Gimenes-Junior, J.A.; Akamine, A.T.; Crippa, J.A.; Tavares-De-Lima, W.; et al. Cannabidiol improves lung function and inflammation in mice submitted to LPS-induced acute lung injury. Immunopharmacol. Immunotoxicol. 2015, 37, 35-41. [CrossRef] [PubMed]

245. Larsen, C.; Shahinas, J. Dosage, Efficacy and Safety of Cannabidiol Administration in Adults: A Systematic Review of Human Trials. J. Clin. Med. Res. 2020, 12, 129-141. [CrossRef]

246. Costiniuk, C.T.; Jenabian, M.A. Acute inflammation and pathogenesis of SARS-CoV-2 infection: Cannabidiol as a potential anti-inflammatory treatment? Cytokine Growth Factor Rev. 2020, 53, 63-65. [CrossRef]

247. Mecha, M.; Feliú, A.; Iñigo, P.M.; Mestre, L.; Carrillo-Salinas, F.J.; Guaza, C. Cannabidiol provides long-lasting protection against the deleterious effects of inflammation in a viral model of multiple sclerosis: A role for A2A receptors. Neurobiol. Dis. 2013. [CrossRef]

248. Kozela, E.; Pietr, M.; Juknat, A.; Rimmerman, N.; Levy, R.; Vogel, Z. Cannabinoids $\Delta$ 9-tetrahydrocannabinol and cannabidiol differentially inhibit the lipopolysaccharide-activated NF- $\mathrm{kB}$ and interferon- $\beta$ /STAT proinflammatory pathways in BV-2 microglial cells. J. Biol. Chem. 2010, 285, 1616-1626. [CrossRef]

249. Vuolo, F.; Petronilho, F.; Sonai, B.; Ritter, C.; Hallak, J.E.C.; Zuardi, A.W.; Crippa, J.A.; Dal-Pizzol, F. Evaluation of Serum Cytokines Levels and the Role of Cannabidiol Treatment in Animal Model of Asthma. Mediat. Inflamm. 2015, 2015. [CrossRef]

250. Giamarellos-Bourboulis, E.J.; Netea, M.G.; Rovina, N.; Akinosoglou, K.; Antoniadou, A.; Antonakos, N.; Damoraki, G.; Gkavogianni, T.; Adami, M.E.; Katsaounou, P.; et al. Complex Immune Dysregulation in COVID-19 Patients with Severe Respiratory Failure. Cell Host Microbe 2020, 27, 992-1000.e3. [CrossRef]

251. Byrareddy, S.N.; Mohan, M. SARS-CoV2 induced respiratory distress: Can cannabinoids be added to anti-viral therapies to reduce lung inflammation? Brain Behav. Immun. 2020, 87, 120. [CrossRef]

252. Wang, B.; Kovalchuk, A.; Li, D.; Ilnytskyy, Y.; Kovalchuk, I. In Search of Preventative Strategies: Novel Anti-Inflammatory High-CBD Cannabis Sativa Extracts Modulate ACE2 Expression in COVID-19 Gateway Tissues. Preprints 2020, 1-12. [CrossRef]

253. Machado Bergamaschi, M.; Helena Costa Queiroz, R.; Waldo Zuardi, A.; Alexandre, S.; Crippa, J. Safety and Side Effects of Cannabidiol, a Cannabis sativa Constituent. Curr. Drug Saf. 2011, 6, 237-249. [CrossRef]

254. Huang, S.; Goplen, N.P.; Zhu, B.; Cheon, I.S.; Son, Y.; Wang, Z.; Li, C.; Dai, Q.; Jiang, L.; Xiang, M.; et al. Macrophage PPAR- $\gamma$ suppresses long-term lung fibrotic sequelae following acute influenza infection. PLoS ONE 2019, 14, e223430. [CrossRef] [PubMed]

255. Ribeiro, A.; Ferraz-De-Paula, V.; Pinheiro, M.L.; Vitoretti, L.B.; Mariano-Souza, D.P.; Quinteiro-Filho, W.M.; Akamine, A.T.; Almeida, V.I.; Quevedo, J.; Dal-Pizzol, F.; et al. Cannabidiol, a non-psychotropic plant-derived cannabinoid, decreases inflammation in a murine model of acute lung injury: Role for the adenosine A 2A receptor. Eur. J. Pharmacol. $2012,678,78-85$. [CrossRef]

256. Costa, L.; Amaral, C.; Teixeira, N.; Correia-da-Silva, G.; Fonseca, B.M. Cannabinoid-induced autophagy: Protective or death role? Prostaglandins Other Lipid Mediat. 2016, 122, 54-63. [CrossRef] [PubMed]

257. Koay, L.C.; Rigby, R.J.; Wright, K.L. Cannabinoid-induced autophagy regulates suppressor of cytokine signaling-3 in intestinal epithelium. Am. J. Physiol. Gastrointest. Liver Physiol. 2014, 307, 140-148. [CrossRef]

258. McAllister, S.D.; Murase, R.; Christian, R.T.; Lau, D.; Zielinski, A.J.; Allison, J.; Almanza, C.; Pakdel, A.; Lee, J.; Limbad, C.; et al Pathways mediating the effects of cannabidiol on the reduction of breast cancer cell proliferation, invasion, and metastasis. Breast Cancer Res. Treat. 2011, 129, 37-47. [CrossRef]

259. Hayashi, H.; Tsuchiya, Y.; Nakayama, K.; Satoh, T.; Nishida, E. Down-regulation of the PI3-kinase/Akt pathway by ERK MAP kinase in growth factor signaling. Genes Cells 2008, 13, 941-947. [CrossRef] [PubMed]

260. Hiebel, C.; Kromm, T.; Stark, M.; Behl, C. Cannabinoid receptor 1 modulates the autophagic flux independent of mTOR- and BECLIN1-complex. J. Neurochem. 2014, 131, 484-497. [CrossRef]

261. Richards, A.L.; Jackson, W.T. That which does not degrade you makes you stronger. Autophagy 2013, 9, 806-807. [CrossRef]

262. Choi, Y.; Bowman, J.W.; Jung, J.U. Autophagy during viral infection-A double-edged sword. Nat. Rev. Microbiol. 2018, 16, 341-354. [CrossRef] [PubMed] 
263. Hannan, M.A.; Rahman, M.A.; Rahman, M.S.; Sohag, A.A.M.; Dash, R.; Hossain, K.S.; Farjana, M.; Uddin, M.J. Intermittent fasting, a possible priming tool for host defense against SARS-CoV-2 infection: Crosstalk among calorie restriction, autophagy and immune response. Immunol. Lett. 2020, 226, 38-45. [CrossRef]

264. Johnson, J.B.; Summer, W.; Cutler, R.G.; Martin, B.; Hyun, D.H.; Dixit, V.D.; Pearson, M.; Nassar, M.; Tellejohan, R.; Maudsley, S.; et al. Alternate day calorie restriction improves clinical findings and reduces markers of oxidative stress and inflammation in overweight adults with moderate asthma. Free Radic. Biol. Med. 2007, 42, 665-674. [CrossRef]

265. Calender, A.; Israel-Biet, D.; Valeyre, D.; Pacheco, Y. Modeling Potential Autophagy Pathways in COVID-19 and Sarcoidosis. Trends Immunol. 2020, 41, 856-859. [CrossRef]

266. Molina-Molina, M.; Machahua-Huamani, C.; Vicens-Zygmunt, V.; Llatjós, R.; Escobar, I.; Sala-Llinas, E.; Luburich-Hernaiz, P.; Dorca, J.; Montes-Worboys, A. Anti-fibrotic effects of pirfenidone and rapamycin in primary IPF fibroblasts and human alveolar epithelial cells. BMC Pulm. Med. 2018, 18, 63. [CrossRef] [PubMed]

267. Omarjee, L.; Janin, A.; Perrot, F.; Laviolle, B.; Meilhac, O.; Mahe, G. Targeting T-cell senescence and cytokine storm with rapamycin to prevent severe progression in COVID-19. Clin. Immunol. 2020, 216, 108464. [CrossRef] [PubMed]

268. Wang, Y.; Zhang, D.; Du, G.; Du, R.; Zhao, J.; Jin, Y.; Fu, S.; Gao, L.; Cheng, Z.; Lu, Q.; et al. Remdesivir in adults with severe COVID-19: A randomised, double-blind, placebo-controlled, multicentre trial. Lancet 2020, 395, 1569-1578. [CrossRef]

269. Uzun, T.; Toptas, O. Artesunate: Could be an alternative drug to chloroquine in COVID-19 treatment? Chin. Med. 2020, 15, 54. [CrossRef]

270. Khan, N.; Halcrow, P.W.; Lakpa, K.L.; Afghah, Z.; Miller, N.M.; Dowdy, S.F.; Geiger, J.D.; Chen, X. Two-pore channels regulate Tat endolysosome escape and Tat-mediated HIV-1 LTR transactivation. FASEB J. 2020, 34, 4147-4162. [CrossRef] [PubMed]

271. Pizzorno, A.; Padey, B.; Dubois, J.; Julien, T.; Traversier, A.; Dulière, V.; Brun, P.; Lina, B.; Rosa-Calatrava, M.; Terrier, O. In vitro evaluation of antiviral activity of single and combined repurposable drugs against SARS-CoV-2. Antivir. Res. 2020, 181, 104878. [CrossRef]

272. Kang, C.K.; Seong, M.W.; Choi, S.J.; Kim, T.S.; Choe, P.G.; Song, S.H.; Kim, N.J.; Park, W.B.; Oh, M.D. In vitro activity of lopinavir/ritonavir and hydroxychloroquine against severe acute respiratory syndrome coronavirus 2 at concentrations achievable by usual doses. Korean J. Intern. Med. 2020, 35, 782-787. [CrossRef]

273. Choy, K.T.; Wong, A.Y.L.; Kaewpreedee, P.; Sia, S.F.; Chen, D.; Hui, K.P.Y.; Chu, D.K.W.; Chan, M.C.W.; Cheung, P.P.H.; Huang, X.; et al. Remdesivir, lopinavir, emetine, and homoharringtonine inhibit SARS-CoV-2 replication in vitro. Antivir. Res. 2020, 178, 104786. [CrossRef]

274. Chu, C.M.; Cheng, V.C.C.; Hung, I.F.N.; Wong, M.M.L.; Chan, K.H.; Chan, K.S.; Kao, R.Y.T.; Poon, L.L.M.; Wong, C.L.P.; Guan, Y.; et al. Role of lopinavir/ritonavir in the treatment of SARS: Initial virological and clinical findings. Thorax 2004, 59, 252-256. [CrossRef] [PubMed]

275. De Wilde, A.H.; Jochmans, D.; Posthuma, C.C.; Zevenhoven-Dobbe, J.C.; Van Nieuwkoop, S.; Bestebroer, T.M.; Van Den Hoogen, B.G.; Neyts, J.; Snijder, E.J. Screening of an FDA-approved compound library identifies four small-molecule inhibitors of Middle East respiratory syndrome coronavirus replication in cell culture. Antimicrob. Agents Chemother. 2014, 58, 4875-4884. [CrossRef] [PubMed]

276. Kuba, K.; Imai, Y.; Rao, S.; Gao, H.; Guo, F.; Guan, B.; Huan, Y.; Yang, P.; Zhang, Y.; Deng, W.; et al. A crucial role of angiotensin converting enzyme 2 (ACE2) in SARS coronavirus-induced lung injury. Nat. Med. 2005, 11, 875-879. [CrossRef] [PubMed]

277. Manuzak, J.A.; Gott, T.M.; Kirkwood, J.S.; Coronado, E.; Hensley-Mcbain, T.; Miller, C.; Cheu, R.K.; Collier, A.C.; Funderburg, N.T.; Martin, J.N.; et al. Heavy Cannabis Use Associated with Reduction in Activated and Inflammatory Immune Cell Frequencies in Antiretroviral Therapy-Treated Human Immunodeficiency Virus-Infected Individuals. Clin. Infect. Dis. 2018, 66, 1872-1882. [CrossRef]

278. Rizzo, M.D.; Crawford, R.B.; Henriquez, J.E.; Aldhamen, Y.; Gulick, P.; Amalfitano, A.; Kaminski, N.E. HIV-infected cannabis users have lower circulating CD16+ monocytes and IP-10 levels compared to non-using HIV patients. AIDS 2017, $32,419$. [CrossRef]

279. National Library of Medicine National Center for Biotechnology Information. PubChem Database. Explore Chemistry. Available online: https: / / pubchem.ncbi.nlm.nih.gov / (accessed on 2 January 2021). 